\title{
Analysis of Crack Width Development in Reinforced Concrete Beams
}

\author{
Barbara Goszczyńska (1), Wiesław Trąmpczyński *(D) and Justyna Tworzewska
}

Citation: Goszczyńska, B.;

Trąmpczyński, W.; Tworzewska, J. Analysis of Crack Width Development in Reinforced Concrete Beams.

Materials 2021, 14, 3043. https:// doi.org/10.3390/ma14113043

Academic Editor: Lukasz Sadowski

Received: 10 May 2021

Accepted: 29 May 2021

Published: 3 June 2021

Publisher's Note: MDPI stays neutral with regard to jurisdictional claims in published maps and institutional affiliations.

Copyright: (c) 2021 by the authors. Licensee MDPI, Basel, Switzerland. This article is an open access article distributed under the terms and conditions of the Creative Commons Attribution (CC BY) license (https:// creativecommons.org/licenses/by/ $4.0 /)$.
Faculty of Civil Engineering and Architecture, Kielce University of Technology, Al. Tysiąclecia Państwa Polskiego 7, 25-314 Kielce, Poland; bgoszczynska@tu.kielce.pl (B.G.); j.tworzewska@tu.kielce.pl (J.T.)

* Correspondence: wtramp@tu.kielce.pl; Tel.: +48-608-052-184

Abstract: The reliability and durability of reinforced concrete structures depend on the amount of concrete cracking. The risk associated with cracks generates a need for diagnostic methods for the evaluation of reinforced concrete structures. This paper presents the results of a study of 10 single-span reinforced concrete beams to follow the process of crack formation and changes in their width. The beams were loaded to failure with two forces in a monotonic manner with unloading and in a cyclic manner. Continuous observation of the crack formation process was provided by the digital image correlation system. The simplified method for estimating the maximum crack width is proposed. The presented results confirmed the stochastic character of the process of crack formation and development. The maximum crack widths calculated on the basis of the proposed formula were on the safe side in relation to those calculated according to Eurocode 2. It was also confirmed that the distances between cracks do not depend on the loading manner. Hence the density function describing the distribution of distances between cracks can be used to assess the condition of reinforced concrete elements. The research has also shown the suitability of the DIC system (ARAMIS) for testing concrete elements.

Keywords: reinforced concrete; crack initiation and development; monotonic and cyclic load; simple description of crack width; crack width calculation; digital image correlation

\section{Introduction}

Concrete is the most extensively used material in the construction process, with the annual global consumption level at 4.2 billion tonnes by volume [1]. Its properties are constantly enhanced, allowing the erection of very-complex buildings and engineering structures.

The main benefits of this composite material include strength, durability, shock resistance, relatively low deformability, high fire resistance, and resistance to temperature and moisture fluctuations. It provides a high degree of stiffness and is easy to make into any shape. These properties make concrete a safe and durable option for various construction purposes-from civil engineering to residential to hydraulic engineering projects.

Reinforced concrete (RC) structures, most common among the structures built from concrete, are exposed to static and dynamic loads, extreme weather and cyclic temperature changes. As a result of physical, chemical, mechanical, physicochemical and biological impacts, the structural materials used in making RC structures deteriorate, thereby shortening their safe use.

Advances in technology have resulted in a trend towards the use of increasingly higher strength concrete and steel. Economical use of high quality and high ductility steel leads to correspondingly larger deformations, contributing to an increase in displacements and crack widths. These effects are not relevant for the load-bearing capacity of reinforced concrete elements, but they have a decisive influence on the structure's performance, durability included. Not surprisingly, with the changing performance characteristics of concrete and steel, the state of cracking is still a subject of research. 
The multitude of factors contribute to concrete cracking [2-9]. The heterogeneity of materials and the complex state of stresses and strains accompanying the crack formation make the descriptions of these phenomena be constantly modified, especially from a practical point of view. There are two approaches for the study of concrete cracking.

One relies on the fracture mechanics and concrete resistance modeling of concrete [10-17] which considers the concrete mix components, internal damage, stresses and temperature.

The second approach, applied in this paper, involves tracking the changes in crack formation and crack width to develop diagnostic methods for the evaluation of reinforced concrete structures whose condition depends on the intensity of cracking. Cracking intensity is the number of cracks per unit length a member and the crack width which determines the reinforcement corrosion risk. Random variables influence the crack width size; hence the crack width is also a random variable of which the probabilistic or the evaluation properties follow a normal or log-normal distribution. In terms of the limit states, In the limit states view, the maximum crack width is a quantile at $\beta$, where the probability of this event $\beta$ is fixed a priori and can be a function of the purpose and durability of the structure. From a practical point of view, of particular importance is the maximum crack width estimation accuracy, which decides the risk of corrosion [18]. Corrosion significantly affects the durability of $R C$ structures as it is the leading cause of their deterioration $[6,19,20]$.

Although various crack width estimation methods have been developed over the years, research needs to be continued $[4-7,13,21]$. The proposed relationships are fairly complicated and largely based on many empirical coefficients that take account of concrete composition and strength characteristics, way of curing, loading scheme, cover thickness, type and diameter of reinforcing bars. New and simplified techniques for crack width estimation must be found, particularly reflecting the stochastic nature of the crack formation process [2]. The search for the new methods is aided by modern apparatus [3,4,22,23] that allows continuous monitoring of crack propagation and measuring crack width under dynamic loads.

This paper presents the results of a broad-range program of testing reinforced concrete beams subjected to monotonic loading with unloading and cyclic loading. The research was conducted with a view to developing a method of diagnosing reinforced concrete bridges.

In parallel, work was carried out on diagnostics using acoustic emission technique [24,25].

Since the durability of reinforced concrete structures depends on the intensity of cracking and crack widths, a parallel topic of tracking the process of crack formation and development was undertaken. A known density function for inter-crack distances and crack widths under loading will allow the development of a method for RC structure condition diagnosis based on artificial intelligence. A diagnosis that relies on methods, i.e., acoustic emission and artificial intelligence will be much more reliable, particularly in difficult cases.

The formation of cracks and their development was recorded using the ARAMIS digital image correlation (DIC) system. The system provides a 3D real time display of strain field overlaid on live image, thereby allowing a continuous measurement of crack widths. The use of a power supply system with a controller, which was synchronized with the measuring equipment, enabled the implementation of cyclic loads.

The crack width test results were compared with those calculated according to EC2 [26] and with the results of the estimated crack width perpendicular to the element axis obtained with the simplified formula. The simplified formula is based on the previously proposed probabilistic model of the inter-crack fields [27]. It was demonstrated that the crack formation is a stochastic process and that the maximum width can be described by a relatively simple, loading mode independent relationship. 


\section{Test Program}

\subsection{Beams and Beam Designation}

Ten reinforced concrete $(\mathrm{RC})$ beams manufactured at the prefabrication plant producing bridge elements were subjected to bending tests. The beams were simply supported and had two concentrated loads applied at a distance of $1 \mathrm{~m}$ from the supports. The beams, each $120 \mathrm{~mm} \times 300 \mathrm{~mm}$ in cross section and $3300 \mathrm{~mm}$ in length ( $3000 \mathrm{~mm}$ effective span), were ordered from concrete C40/50, and the bars were made of B500S (class B) steel. The longitudinal reinforcement ratio at the beam tension zone was $2 \%$. Four of the beams were designed without stirrups, and two had no compression reinforcement in the central section. Different loading regimes were applied: monotonically increasing load until failure, loading and unloading and low-cycle loading. The tested members are shown in Table 1. Beam designation followed the pattern shown in Figure 1.

Table 1. Summary of beam data.

\begin{tabular}{|c|c|c|c|c|c|}
\hline \multirow{2}{*}{$\begin{array}{c}\text { Reinforcement } \\
\text { Design Symbol } \\
\text { and Ratio }\end{array}$} & \multicolumn{3}{|c|}{ Reinforcement } & \multirow[b]{2}{*}{ Loading Program } & \multirow[b]{2}{*}{ Number of Beams } \\
\hline & $\begin{array}{c}\text { Tension } \\
\text { Reinforcement }\end{array}$ & $\begin{array}{l}\text { Compression } \\
\text { Reinforcement }\end{array}$ & Stirrups & & \\
\hline A2 & \multirow{5}{*}{$\begin{array}{l}3 \phi 12 \text { - first row } \\
2 \phi 14 \text {-second row }\end{array}$} & $2 \phi 8$ & + & $\mathrm{M}-$ monotonic & 2 \\
\hline A2 & & $2 \phi 8$ & + & $\begin{array}{l}\mathrm{O} \text {-with } \\
\text { unloading }\end{array}$ & 2 \\
\hline $\mathrm{A} 2$ & & $2 \phi 8$ & + & C-low-cycle & 2 \\
\hline $\mathrm{C} 2$ & & $\begin{array}{c}\text { None in the } \\
\text { midspan section of } \\
\text { the beam (ca.1m) }\end{array}$ & $\begin{array}{l}\text { None in the } \\
\text { midspan section of } \\
\text { the beam (ca.1m) }\end{array}$ & $\mathrm{M}$-monotonic & 2 \\
\hline D2 & & $2 \phi 8$ & $\begin{array}{l}\text { None in the } \\
\text { midspan section of } \\
\text { the beam (ca.1m) }\end{array}$ & $\mathrm{M}-$ monotonic & 2 \\
\hline
\end{tabular}

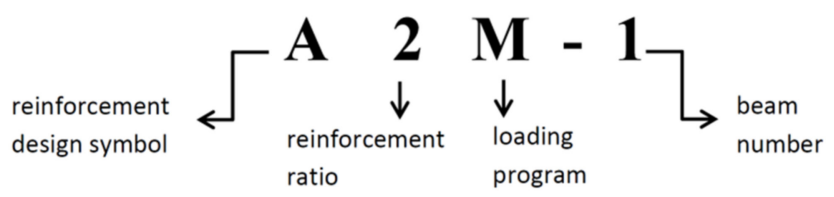

Figure 1. Beam designation key.

Material composition and properties of the concrete mixture obtained from prefabrication plant for concrete grade $\mathrm{C} 40 / 50$ :

- Cement CEM I 52,5N HSR NA Chełm-390 kg

- Water-cement ratio 0.4

- Water-155 kg

- $\quad$ Aggregates-basalt 8/16-694 kg (35.2\%), basalt 2/8-617 kg (31.3\%), river sand 0/2$660 \mathrm{~kg}(33.5 \%)$

- $\quad$ Superplasticizer- $1.84 \mathrm{~kg}$

- Air entraining agent- $0.47 \mathrm{~kg}$.

The beam reinforcement design with or without longitudinal bars at the compression zone and with or without stirrups in the midspan section of the beam is illustrated in Figures 2-4. 
Beam A2
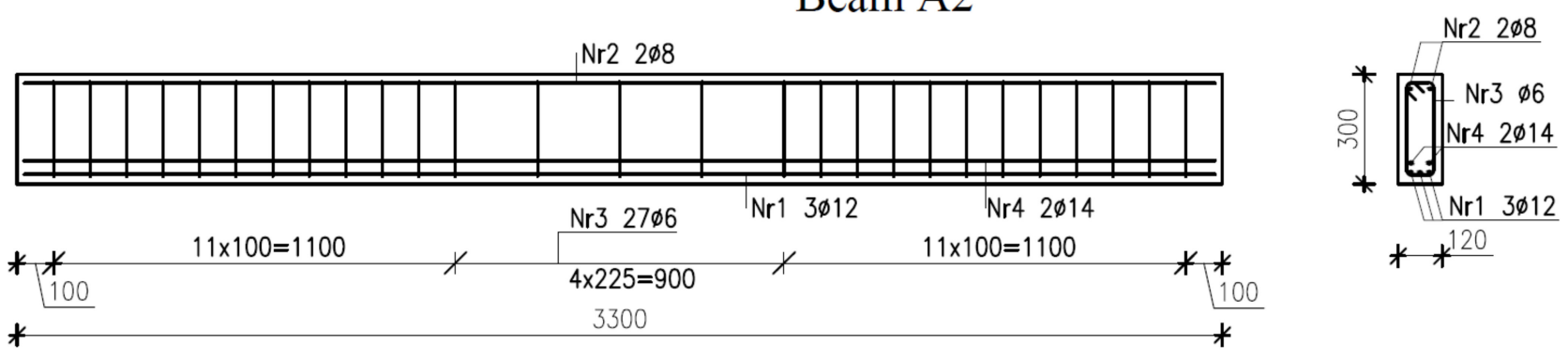

Figure 2. Reinforcement in beams A2.

\section{Beam D2}

$\mathrm{Nr} 22 \varnothing 8$
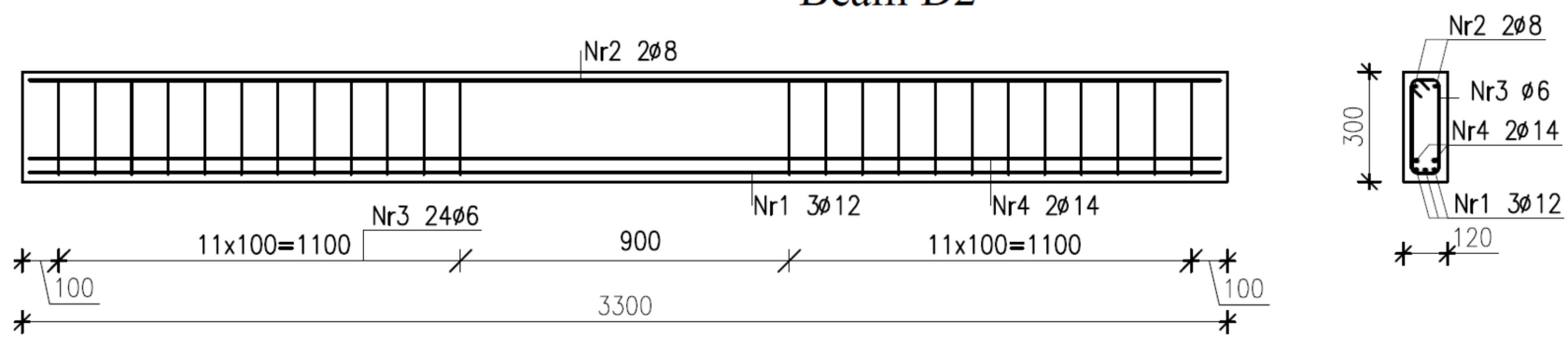

Figure 3. Reinforcement in beams D2.

\section{Beam C2}
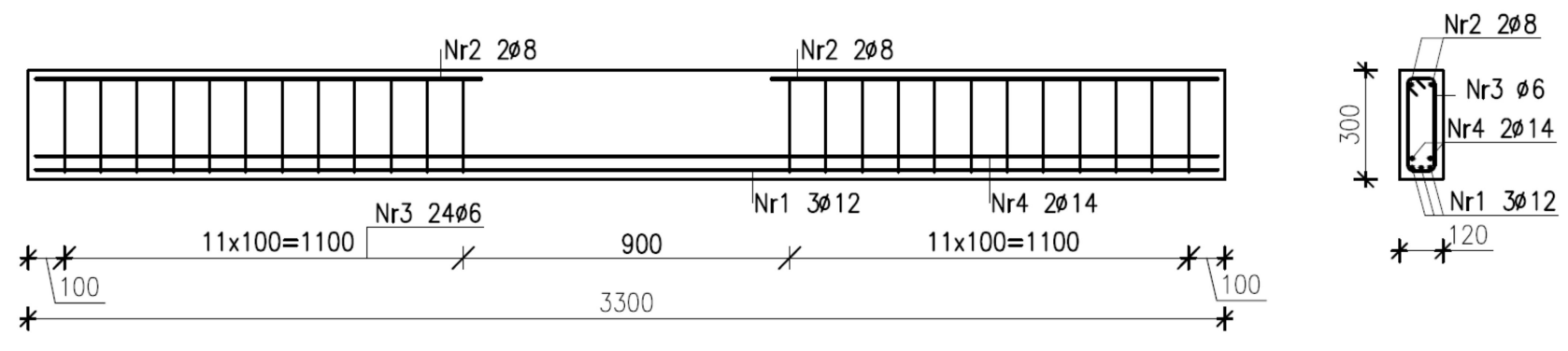

Figure 4. Reinforcement in beams C2.

\subsection{Loading Diagram and Program}

Figure 5 shows a static scheme of beams A2, C2 and D2, for which the reinforcement and load applied were selected so as to induce failure due to bending moment.

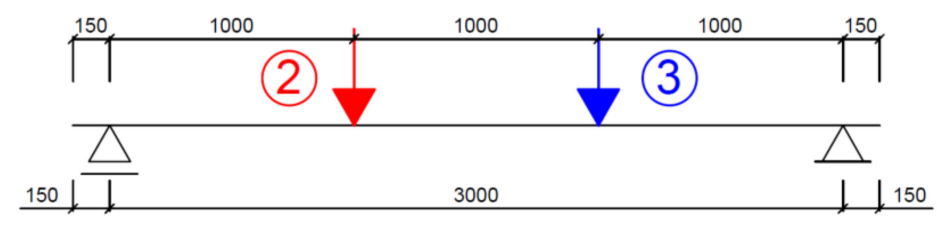

Figure 5. Static scheme of beams A2, D2 and C2.

Three different loading regimes were used, marked as $\mathrm{M}-$ monotonic loading progressively increased to failure, $\mathrm{O}$-loading and unloading, and C-low-cycle loading, as compiled with loading rates in Table 2. The monotonic loading of beams A2, C2 and D2 (two beams of each type) is illustrated in Figure 6. The loading time indicated in Figure 6 corresponds to the tests on beams A2M. Six phases of loading/unloading were used in this study, as shown in Figure 7. The first five phases included ten unloading cycles in each phase at five different loading levels, whereas in phase 6 , the load was increasing to failure. 
Figure 8 illustrates the low-cycle loading performed in four phases. The first three phases included 100,000 cycles per phase at three loading forces: 10, 40 and $58 \mathrm{kN}$. In phase 4, the beam was monotonically loaded to failure. The loading program in particular cycle phases (Figure 8) was implemented by alternatively increasing the loads from $5 \mathrm{kN}$ up to the maximum value at a given phase.

Table 2. Loading program and rate for the members under test.

\begin{tabular}{ccc}
\hline Reinforcement & Loading Regime & Loading Rate \\
\hline A2 & M-monotonic & $0.4 \mathrm{kN} / \mathrm{min}$ \\
\hline A2 & O-loading and unloading & $0.6 \mathrm{kN} / \mathrm{min}$ \\
\hline & & Phase $1-1 \mathrm{~Hz} / \mathrm{s}$ \\
A2 & C-low-cycle & $\begin{array}{c}\text { Phase } 2-0.5 \mathrm{~Hz} / \mathrm{s} \\
\text { Phase } 3-0.5 \mathrm{~Hz} / \mathrm{s} \\
\end{array}$ \\
& Phase $4-0.4 \mathrm{or} 0.6 \mathrm{kN} / \mathrm{min}$ \\
\hline C2 & M-monotonic & $0.4 \mathrm{kN} / \mathrm{min}$ \\
\hline D2 & M-monotonic & $0.4 \mathrm{kN} / \mathrm{min}$ \\
\hline
\end{tabular}

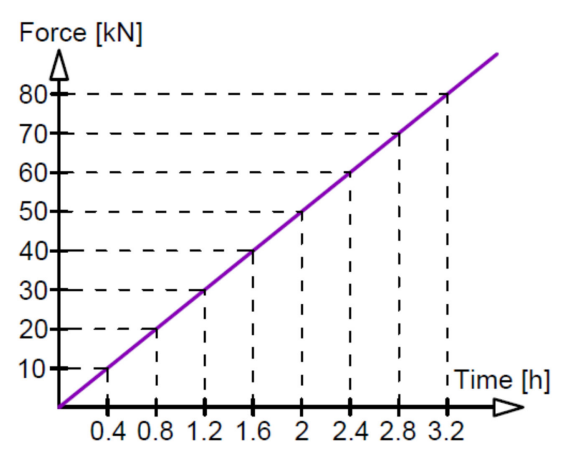

Figure 6. Monotonic loading.

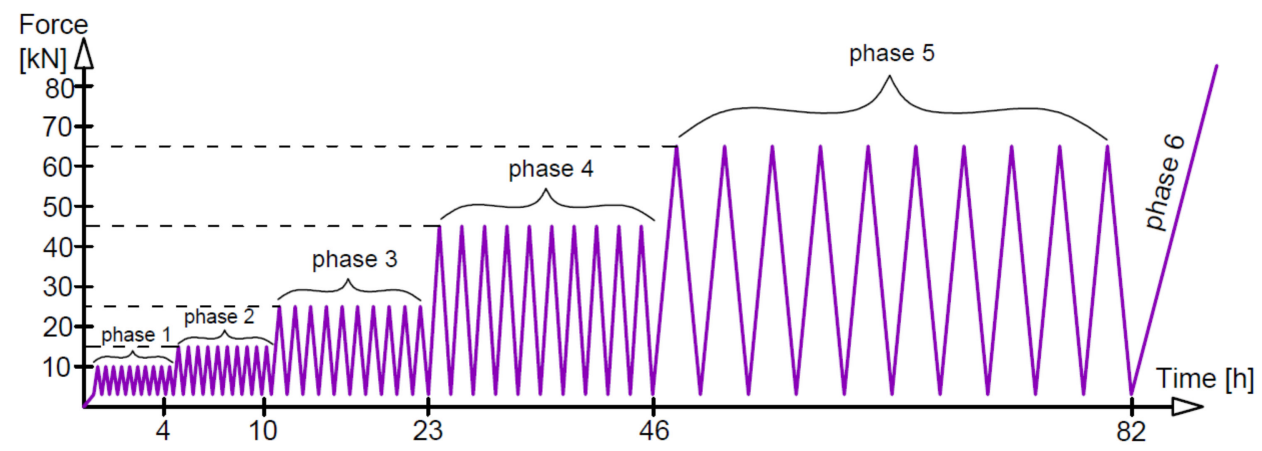

Figure 7. Loading and unloading.

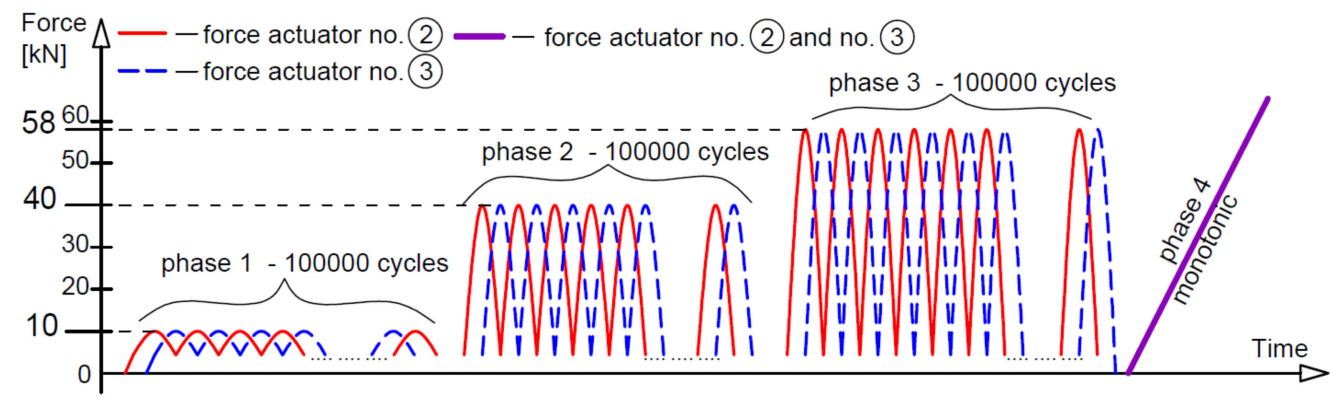

Figure 8. Low-cycle loading. 


\subsection{Additional Tests—Strength of Concrete}

The strength of the concrete was tested on the $150 \mathrm{~mm} \times 150 \mathrm{~mm} \times 150 \mathrm{~mm}$ cuboids fabricated while casting particular concrete beam pairs in the multi-cavity mould. The failure force test results for the concrete cubes, the calculated compressive strength of the concrete and the relevant statistics are presented in Tables 3 and 4, respectively.

Table 3. Summary of failure forces for concrete cubes.

\begin{tabular}{cccccc}
\hline & \multicolumn{5}{c}{ Failure Force (kN) } \\
\hline \multirow{2}{*}{ Beams } & \multicolumn{1}{c}{ A2M, A2O } & C2M & D2M & A2C \\
\cline { 2 - 6 } & 1 & 1699.78 & 1699.16 & 1579.52 & 1598.35 \\
\cline { 2 - 6 } & 2 & 1581.12 & 1525.13 & 1571.93 & 1665.11 \\
\cline { 2 - 6 } $\begin{array}{c}\text { Specimen } \\
\text { Number }\end{array}$ & 3 & 1385.10 & 1509.84 & 1720.55 & 1640.01 \\
\cline { 2 - 6 } & 4 & 1473.84 & 1617.77 & 1590.06 & 1569.47 \\
\cline { 2 - 6 } & 5 & 1591.74 & 1607.50 & 1671.89 & 1722.58 \\
\hline & 6 & 1527.79 & 1664.63 & 1571.92 & 1640.35 \\
\hline
\end{tabular}

Table 4. Compressive strength results for concrete cubes.

\begin{tabular}{cccccc}
\hline \multicolumn{7}{c}{ Compressive Strength (MPa) } \\
\hline Beams & \multicolumn{1}{c}{ A2M, A2O } & C2M & D2M & A2C \\
\hline & 1 & 75.5 & 75.5 & 70.2 & 71.0 \\
\cline { 2 - 6 } Specimen number & 2 & 70.3 & 67.8 & 69.9 & 74.0 \\
\cline { 2 - 6 } & 3 & 61.6 & 67.1 & 76.5 & 72.9 \\
\cline { 2 - 6 } & 4 & 65.5 & 71.9 & 70.7 & 69.8 \\
\cline { 2 - 6 } & 5 & 70.7 & 71.4 & 74.3 & 76.6 \\
\hline Mean & 6 & 67.9 & 74.0 & 69.9 & 72.9 \\
\hline Standard Deviation & $\mathrm{f}$ cube & 68.6 & 71.3 & 71.9 & 72.9 \\
\hline Coefficient of Variation & $\mathrm{s}$ & 4.8 & 3.3 & 2.8 & 2.4 \\
\hline
\end{tabular}

Table 5 compiles the results of calculations for individual pairs of beams:

- Average concrete compressive strength estimated according to (1)

$$
\mathrm{f}_{\mathrm{cm}}^{\mathrm{CYL}}=0.8 \mathrm{f}_{\mathrm{cm}}^{\text {cube }}
$$

- Characteristic concrete compressive strength according to (2)

$$
\mathrm{f}_{\mathrm{ck}}=\mathrm{f}_{\mathrm{cm}}^{\mathrm{CYL}}-8
$$

- Class of concrete

- Modulus of elasticity according to (3)

$$
\mathrm{E}_{\mathrm{cm}}=22\left(0.1 \mathrm{f}_{\mathrm{cm}}^{\mathrm{CYL}}\right)^{0.3}
$$


Table 5. Concrete class.

\begin{tabular}{|c|c|c|c|c|c|}
\hline \multicolumn{2}{|c|}{ Beams } & \multirow{2}{*}{$\begin{array}{c}\text { A2M, A2O } \\
54.9\end{array}$} & \multirow{2}{*}{$\begin{array}{c}\mathbf{C} 2 \mathbf{M} \\
57\end{array}$} & \multirow{2}{*}{$\begin{array}{c}\text { D2M } \\
57.5\end{array}$} & \multirow{2}{*}{$\begin{array}{l}\text { A2C } \\
58.3\end{array}$} \\
\hline $\mathrm{f}_{\mathrm{cm}}^{\mathrm{CYL}}$ & $(\mathrm{MPa})$ & & & & \\
\hline $\mathrm{f}_{\mathrm{ck}}$ & $(\mathrm{MPa})$ & 46.9 & 49 & 49.5 & 50.3 \\
\hline Class & - & $\mathrm{C} 45 / 55$ & $\mathrm{C} 50 / 60$ & C50/60 & $\mathrm{C} 50 / 60$ \\
\hline $\mathrm{E}_{\mathrm{cm}}$ & $(\mathrm{GPa})$ & 36.7 & 37.1 & 37.2 & 37.3 \\
\hline
\end{tabular}

For example, Figure 9 shows the force-strain curves automatically obtained while testing the concrete specimens corresponding to the $\mathrm{A} 2 \mathrm{M}$ and $\mathrm{A} 2 \mathrm{O}$ beams in the Zwick hydraulic press 6000 . For each casting, six cubes were made and then destroyed. The numbers 1,2,3,4,5 and 6 are the specimen numbers. As can be seen from the graph, the ultimate strain amounts to approximately $0.85 \%$ on average, which means much greater ultimate strains than those adopted for the concrete class below C50/60, amounting to approximately $0.35 \%$ [26]. The force-strain relationships obtained during the tests on the remaining beams are very similar to those shown in Figure 9.

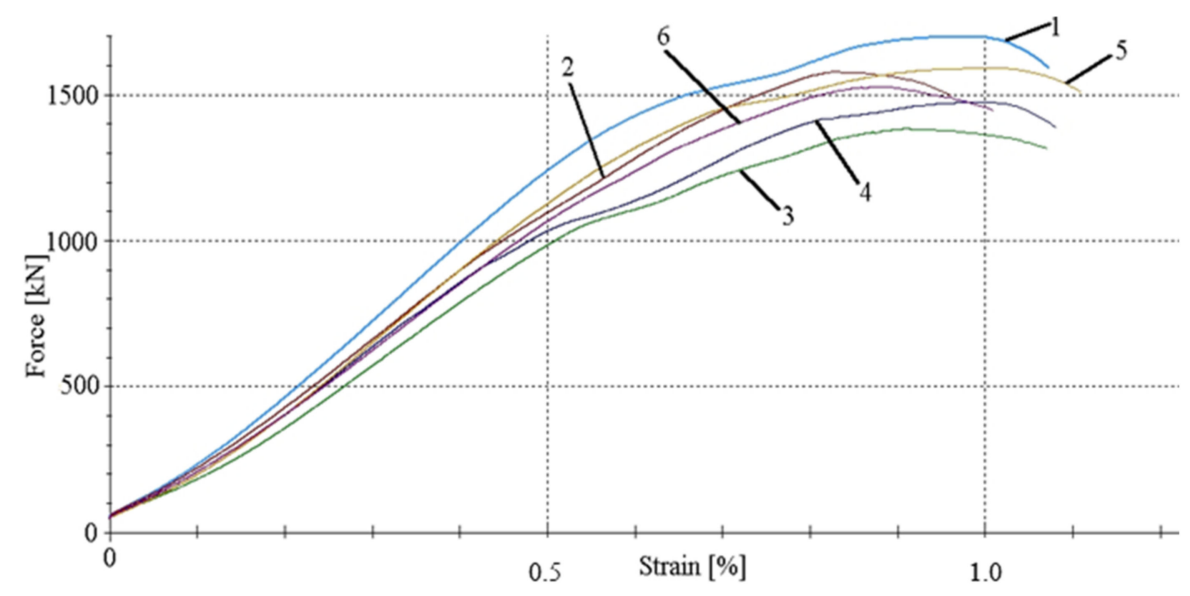

Figure 9. Force-strain relationships for concrete in beams A2M and A2O.

\subsection{Additional Tests-Strength of Steel Bars}

A total of 124 bars used for the main reinforcement were examined, including 58 bars of $\phi 12 \mathrm{~mm}$ and 66 of $\phi 14 \mathrm{~mm}$. Table 6 summarizes the tensile test results and the statistics for the results of the reinforcing bars. The table also shows the automatically obtained results of the elastic modulus $E$, yield strength $R_{p 0.2}$, upper yield point $R_{e H}$ and tensile strength $R_{\mathrm{m}}$.

An example of the stress-strain relationships obtained during the tensile test of BS500 steel bars is shown in Figures 10 and 11. It follows from the graphs that the reinforcing bars were made of high ductility steel. This high ductility of steel distinguishes the currently used steel grades from those used previously, whose brittleness increased with an increase in strength, and even the elastic limit was assumed. 
Table 6. Tensile test results for steel bars.

\begin{tabular}{|c|c|c|c|c|}
\hline \multirow{2}{*}{\multicolumn{2}{|c|}{ Statistics }} & Mean & Standard Deviation & Coefficient of Variation \\
\hline & & $\mathbf{x}$ & $\mathbf{s}$ & $\mathbf{v}$ \\
\hline \multicolumn{5}{|c|}{$58 \phi 12 \mathrm{~mm}$} \\
\hline$E$ & $\mathrm{GPa}$ & 197.17 & 3.59 & 1.82 \\
\hline $\mathrm{R}_{\mathrm{p} 0.2}$ & $\mathrm{MPa}$ & 567.2 & 8.84 & 1.56 \\
\hline $\mathrm{R}_{\mathrm{eH}}$ & $\mathrm{MPa}$ & 570.89 & 7.49 & 1.31 \\
\hline $\mathrm{R}_{\mathrm{m}}$ & $\mathrm{MPa}$ & 657.2 & 5.88 & 0.9 \\
\hline \multicolumn{5}{|c|}{$66 \phi 14 \mathrm{~mm}$} \\
\hline $\mathrm{E}$ & $\mathrm{GPa}$ & 201.41 & 5.13 & 2.55 \\
\hline $\mathrm{R}_{\mathrm{p} 0.2}$ & $\mathrm{MPa}$ & 558.47 & 11.98 & 2.15 \\
\hline $\mathrm{R}_{\mathrm{eH}}$ & $\mathrm{MPa}$ & 561.83 & 12.67 & 2.26 \\
\hline $\mathrm{R}_{\mathrm{m}}$ & $\mathrm{MPa}$ & 636.09 & 8.97 & 1.41 \\
\hline \multicolumn{5}{|c|}{$\phi 12$ and $\phi 14$ (for all 124 bars) } \\
\hline $\mathrm{E}$ & $\mathrm{GPa}$ & 199.42 & 4.94 & 2.48 \\
\hline $\mathrm{R}_{\mathrm{p} 0.2}$ & $\mathrm{MPa}$ & 562.55 & 11.45 & 2.04 \\
\hline $\mathrm{R}_{\mathrm{eH}}$ & $\mathrm{MPa}$ & 567.38 & 10.71 & 1.89 \\
\hline $\mathrm{R}_{\mathrm{m}}$ & $\mathrm{MPa}$ & 645.96 & 13.05 & 2.02 \\
\hline
\end{tabular}

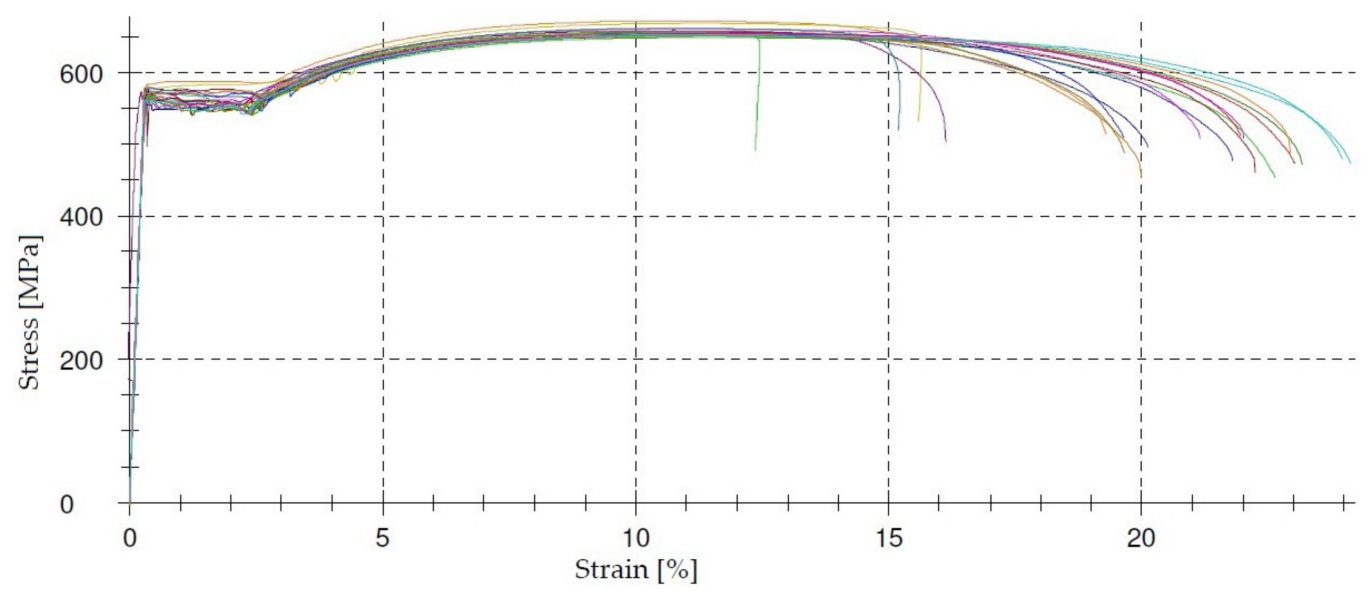

Figure 10. Stress-strain curve for $23 \phi 12$ bars.

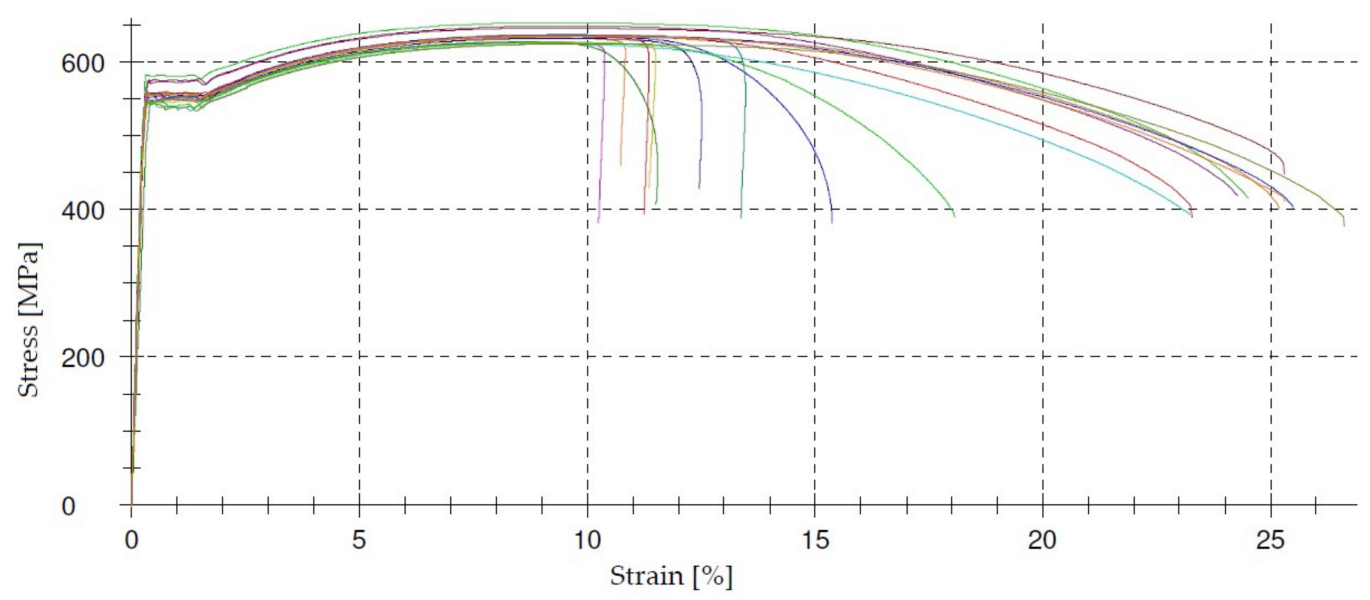

Figure 11. Stress-strain curve for 18 ф 14 bars. 


\section{Test Setup and Instrumentation}

\subsection{Test Setup}

The test setup for the reinforced concrete beams was as shown in Figure 12. The beams were supported by bridge bearings, of which one was fixed, and the loads were imposed automatically by two independent hydraulic actuators of $0-400 \mathrm{kN}$ loading capacity.

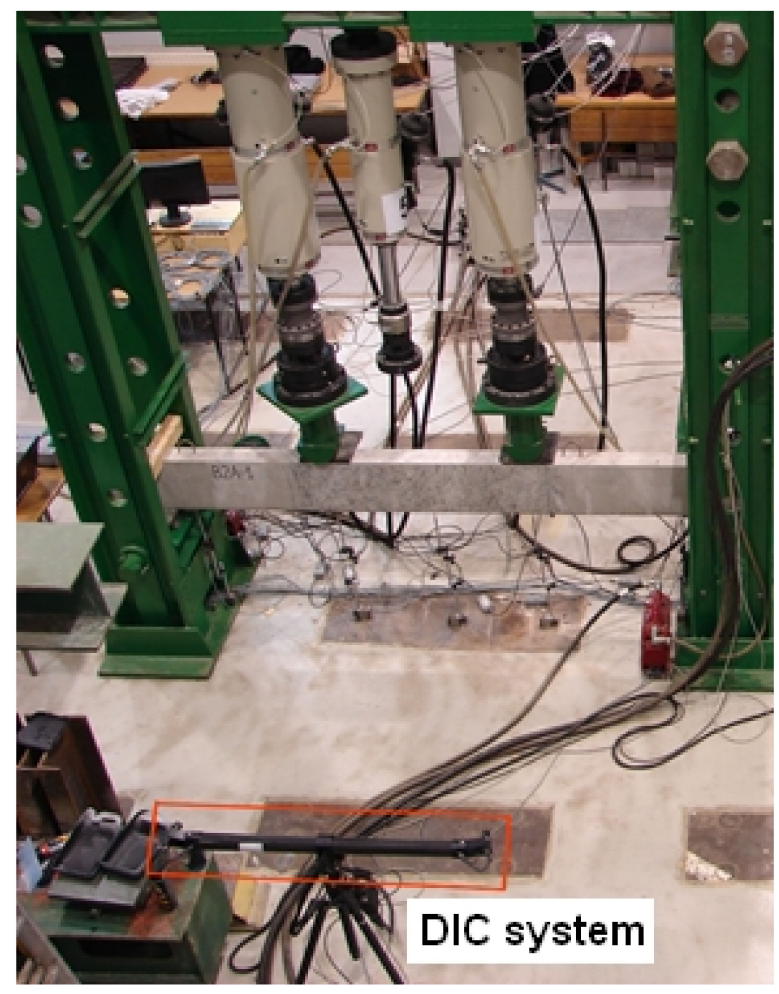

Figure 12. Photo of the test setup.

During the loading, displacements were continuously measured using the HBM measuring system and the field deformation of the middle section of the beam (between forces) by the Digital Image Correlation (DIC) system. The HBM-Hottinger Baldwin Messtechnik system was used to record deflections in the midspan of the beam, under forces and near the supports, while the DIC system was used to measure strains in three directions of the previously prepared central surface, including cracking on the side surface of the beams. The actuator's analogue outputs allowed synchronizing the entire test apparatus, and the recorded force was used to control the HBM and DIC systems measurements. Apparatus synchronization enabled assigning deflection results and the image of strains within the tested field for each force value in the middle section of the beam under load.

\subsection{Crack Width Measurements with DIC System}

DIC is widely used in many fields of science, e.g., biomechanics, astronautics, microelectronics and now also in civil engineering [28-38]. In the experiments, the commercial ARAMIS system was used which is presented in detail in [19,39]. During loading, strains were recorded using the DIC system in the area, as shown in Figure 13. The area between forces was analyzed. The test surface had to be prepared by applying a black paint pattern to enable strain tracking. 


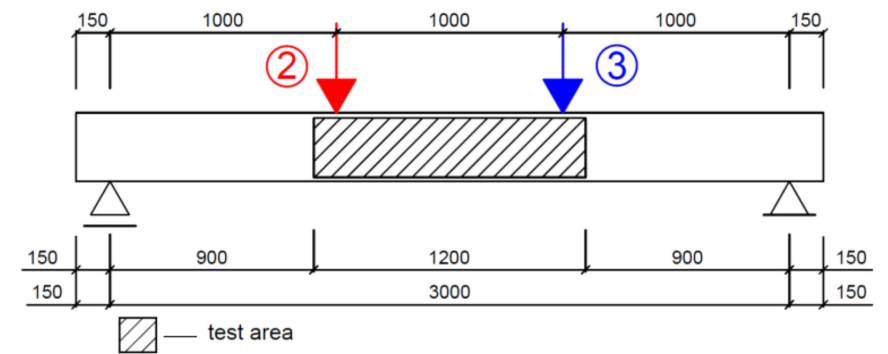

Figure 13. Loading scheme with marked test area.

Analysis of the cracking process in tests conducted with the DIC system is performed after the test has been performed, using the results of calculations for subsequent images presented in the form of strain maps. The system is used for non-contact three-dimensional strain measurements. It performs calculations and documents deformations. The system uses a series of images from two digital cameras on one tripod. It recognizes the surface texture of the sample area in the images. The first photo in the series is treated as a photo of the object before loading and is used as a reference "object". After taking the measurements, the system generates a grid on the first photo. The grid consists of small square or rectangular planes called facets. It assigns each facet a single and unique texture of grey dots. The unique texture makes it possible to find facets in subsequent images. Based on the similarity of the facets in the successive images, the strain of the facets is calculated.

Consecutive images in the form of strain distribution maps are used in the analysis of the cracking process. Figures 14 and 15 include strain map examples for the middle section of the $1000 \mathrm{~mm}$ long beam C2M- 1 at the load level of 0.75 and 0.95 , respectively. The strains on the maps are marked using a colour scale (the log symbol means ln and expresses the fractal measure of deformation).

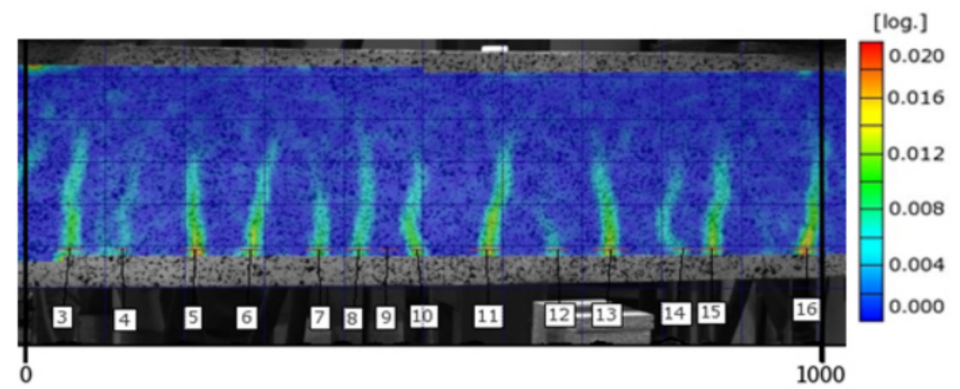

Figure 14. Strain map for beam C2M-1 at the load level of 0.75 .

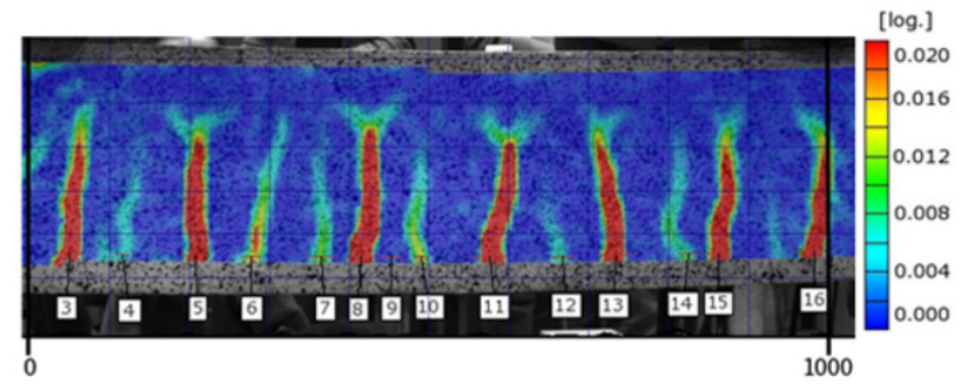

Figure 15. Strain map for beam C2M-1 at the load level of 0.95 .

Analysis of the strain map indicates local strain accumulations at the lower zone of the beam in tension, identified as cracks in concrete (brittle material).

The measurement of the crack width (along the reinforcement centroid line) included computing the change in the length of section $\Delta \mathrm{L}$ at a random force level $[19,39]$ throughout 
the loading process. The measurement scheme is shown in Figure 16. The crack has to be defined in that measurement method to distinguish cracks from surface microcracks and optical noises. In paper [19], a crack was defined as the section length increment of at least $\Delta \mathrm{L}_{\mathrm{i}} \geq 0.05 \mathrm{~mm}$.

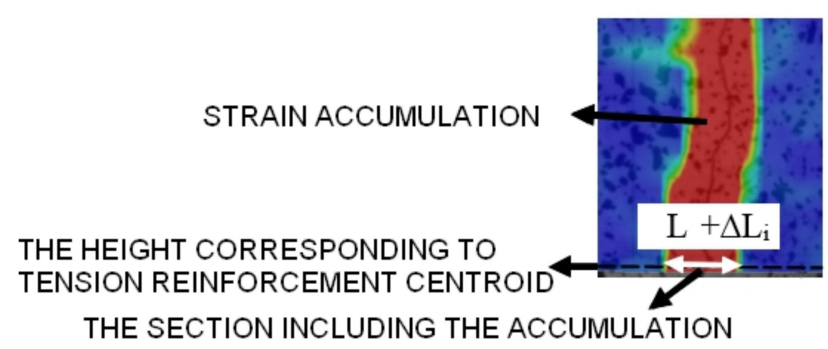

Figure 16. Crack width measurement scheme from DIC system.

To illustrate the correctness of the calculated crack widths, Figure 17 compares the crack width measurement results obtained from the traditional method (with a Brinell magnifying glass) and the DIC system. The test was performed on an additional test beam loaded monotonically to failure with breaks made for measurements with the Brinell magnifier-Figure 18.

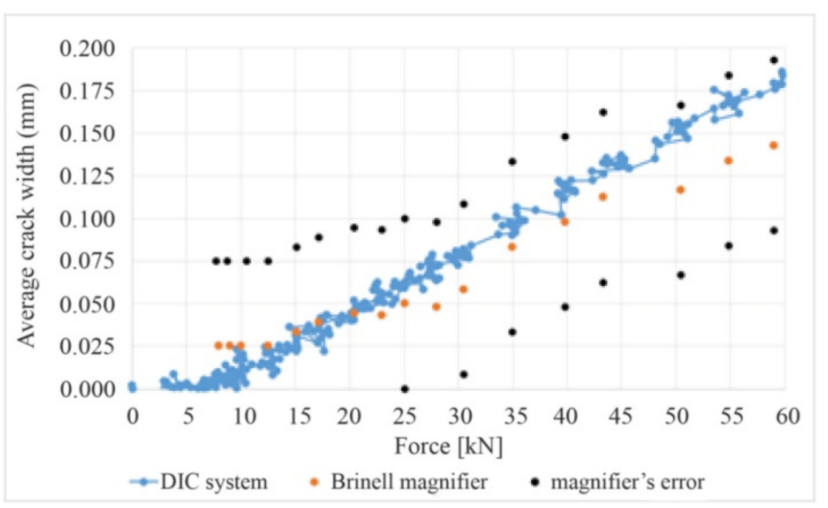

Figure 17. Average crack width from two measurement methods.

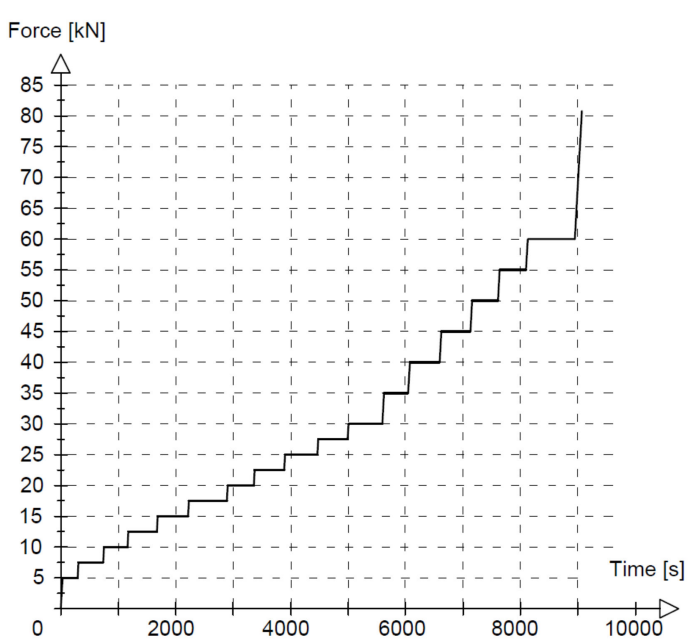

Figure 18. Loading with measurement intervals.

The results obtained with the magnifier and the DIC system fall within the magnifier's error area. Measurement uncertainty, described in [40], is $\pm 0.028 \mathrm{~mm}$. In order to confirm 
the results, the results of deflections obtained from the HBM measuring system and the DIC system were compared and found to be virtually the same [41].

This satisfactory agreement made it possible to use the DIC system to record and measure the quantities describing the cracking state of the beams based on consecutive images. The strain measurements were recorded over the entire prepared area of the beam, thereby enabling the measurement of distances between the cracks and crack widths at the height corresponding to the centroid of the tension reinforcement during loading to failure. The frequency of image triggering events was adjusted to each loading program. The images were captured either at a specified time or at appropriate load values. A single tripod with two cameras was used to capture images every $30 \mathrm{~s}$ for A2M beams and every $20 \mathrm{~s}$ for $\mathrm{C} 2 \mathrm{M}$ and $\mathrm{D} 2 \mathrm{M}$ beams.

When testing A2O beams, the so-called "triggerlist" was used, and a program for taking images triggered by a defined voltage corresponding to a given load was written. The photos were taken with one DIC system tripod with two cameras at defined force levels, as shown in Figure 19, where the dots represent the images taken. During phase 6, i.e., with the load gradually increasing to failure, the images were captured every $10 \mathrm{~s}$.

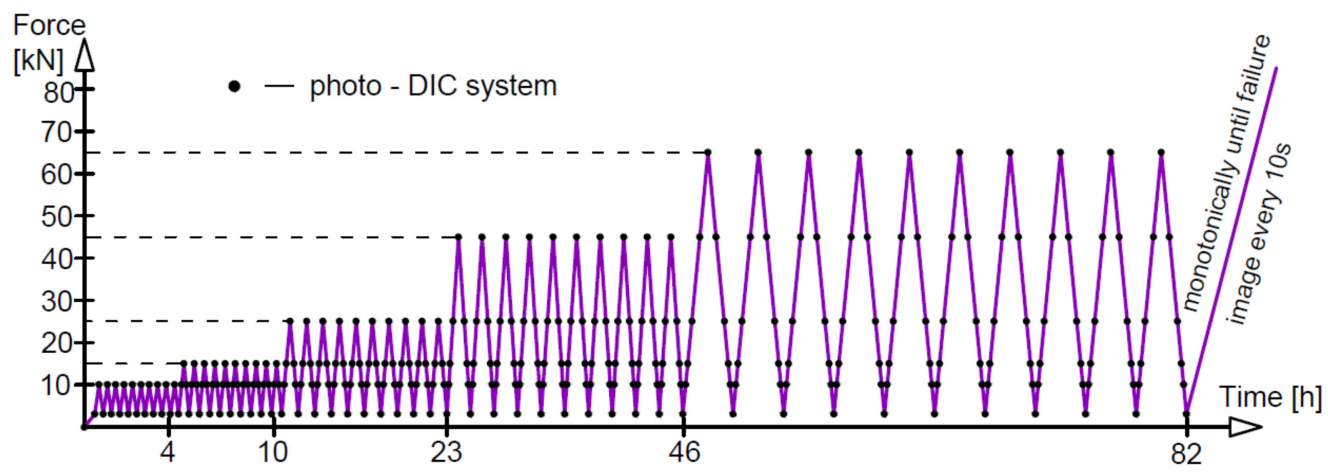

Figure 19. Digital imaging scheme for beams A2O.

For beams A2C, the images were captured intermittently due to the limited system memory. In this way, with each image, one actuator achieved the maximum load for a given phase, and the other actuator-the minimum load, because the actuators worked with a phase shift, i.e., alternately, as shown in Figure 20. Then there was a break of 1500s, after which the process repeated. During phase 4 of monotonic loading to failure, images were taken at intervals of $30 \mathrm{~s}$.

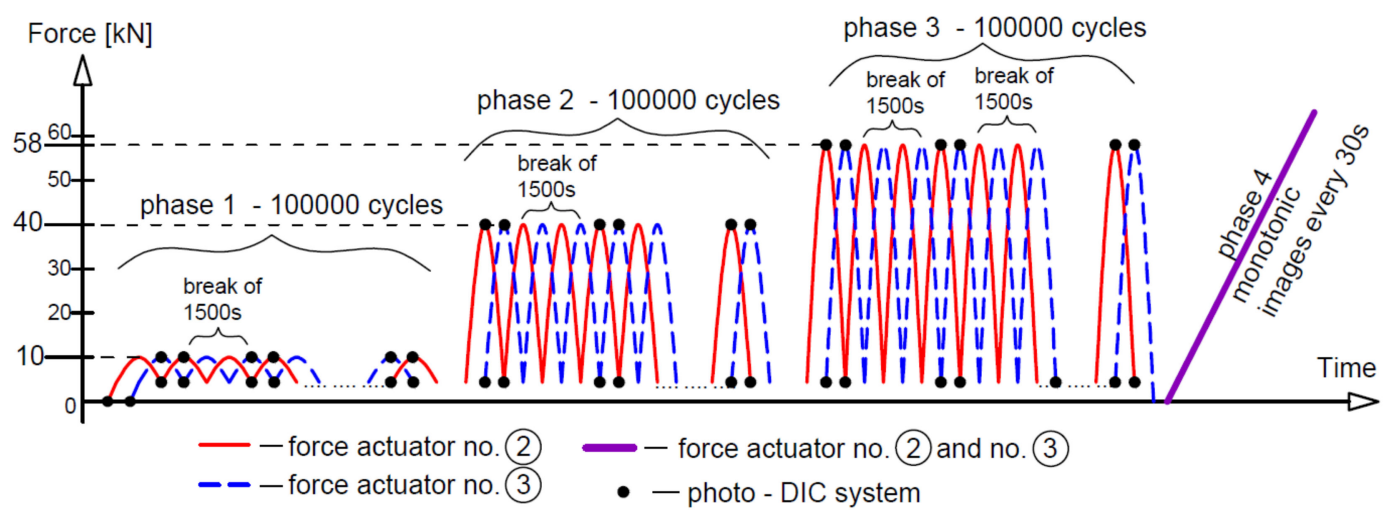

Figure 20. Digital imaging scheme for beams A2C. 


\section{Test Results}

Three quantities typically characterize the cracking state. These are the cracking moment $\mathrm{M}_{\mathrm{cr}}$, the distance between the cracks $\mathrm{s}_{\mathrm{r}}$ and the crack width $\mathrm{w}$. The last two of these quantities are functions of primarily the bending moment $\mathrm{M}$, which can be written as:

$$
\begin{aligned}
& \mathrm{s}_{\mathrm{r}}=\mathrm{f}(\mathrm{M}) \\
& \mathrm{w}=\mathrm{f}(\mathrm{M})
\end{aligned}
$$

All these characteristics are interrelated. It can easily be shown that the cracking moment is a special property of these functions (4) and (5), because for $\mathrm{M}<\mathrm{M}_{\mathrm{cr}}$, the distance between the cracks would be greater than the beam length, and the crack width would be zero. The crack width and the distance between the cracks are thus strongly interrelated. Accordingly, the results of the RC beam test are presented for these three quantities.

The use of the DIC system in this study enabled the analysis of crack formation and development processes (cracking moment, crack width and distance between the cracks) for the loading program specified in Table 2.

Figures 21 and 22 show an image the cracking state on the A2M-2 beam at the load level of 0.75 and 0.95 , respectively, failure load. The calculation mask (deformation map) applied to the side surface of the beam after tests allows the observation of cracks at any selected load level, as illustrated in Figures 21 and 22 (crack numbers are added in the middle section of the $1000 \mathrm{~mm}$ long beam).

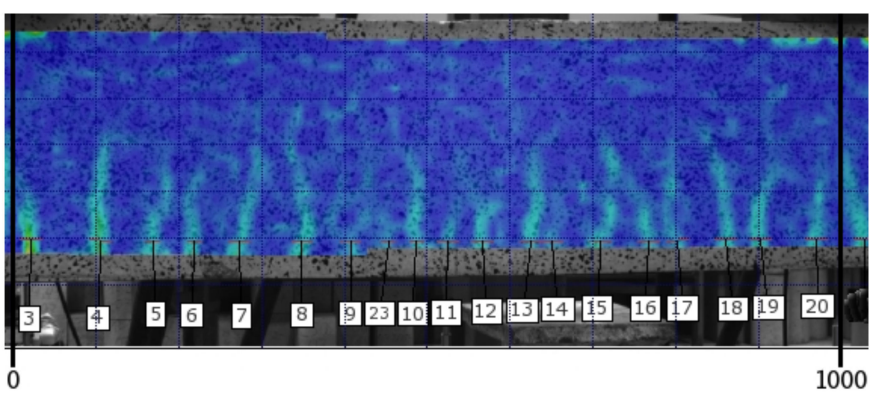

Figure 21. Strain map of the middle section of beam A2M-2 at the load level of 0.75 .

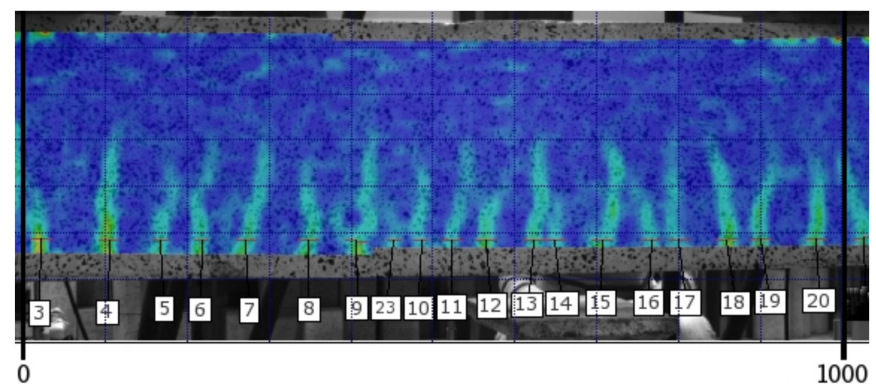

Figure 22. Strain map of the middle section of beam A2M-2 at the load level of 0.95.

As an example, Table 7 summarizes the crack width measurement results for cracks number $4,5 \ldots 13$ (at the height corresponding to the centroid of tension reinforcement) for the A2M-2 beam, calculated from the consecutive images numbered 212 to 224 . The sign $\mathrm{X}$ indicates the location of the crack on the beam's middle section between the loads, where the moment is constant or approximately constant. Table 8 shows the results of the crack width measurements at the load level of 0.75 and 0.95 of the actual damage force. 
Table 7. Crack width results for beam A2M-2 (consecutive images).

\begin{tabular}{|c|c|c|c|c|c|c|c|c|c|c|c|c|}
\hline & Location X $(\mathrm{mm}$ & & 100 & 160 & 200 & 260 & 330 & 390 & 460 & 500 & 540 & 600 \\
\hline \multirow[b]{2}{*}{ Image No. } & \multirow[b]{2}{*}{ Actuator No.2 (kN) } & \multirow[b]{2}{*}{ Actuator No.3 (kN) } & \multicolumn{10}{|c|}{ Crack No. } \\
\hline & & & 4 & 5 & 6 & 7 & 8 & 9 & 10 & 11 & 12 & 13 \\
\hline 212 & 43.08 & 42.98 & 0.147 & 0.085 & 0.065 & 0.102 & 0.075 & 0.027 & 0.055 & 0.051 & 0.083 & 0.092 \\
\hline 213 & 43.14 & 43.05 & 0.162 & 0.035 & 0.074 & 0.107 & 0.087 & 0.038 & 0.069 & 0.030 & 0.102 & 0.037 \\
\hline 214 & 42.26 & 42.00 & 0.143 & 0.066 & 0.070 & 0.099 & 0.076 & 0.039 & 0.046 & 0.028 & 0.104 & 0.078 \\
\hline 215 & 41.67 & 41.54 & 0.129 & 0.039 & 0.071 & 0.088 & 0.096 & 0.028 & 0.082 & 0.028 & 0.105 & 0.082 \\
\hline 216 & 43.23 & 43.04 & 0.129 & 0.068 & 0.063 & 0.073 & 0.075 & 0.041 & 0.089 & 0.030 & 0.095 & 0.052 \\
\hline 217 & 43.54 & 43.35 & 0.140 & 0.082 & 0.068 & 0.072 & 0.092 & 0.040 & 0.083 & 0.026 & 0.103 & 0.057 \\
\hline 218 & 43.36 & 43.24 & 0.114 & 0.089 & 0.071 & 0.081 & 0.092 & 0.041 & 0.053 & 0.041 & 0.105 & 0.080 \\
\hline 219 & 43.44 & 43.31 & 0.122 & 0.079 & 0.070 & 0.088 & 0.088 & 0.044 & 0.037 & 0.039 & 0.095 & 0.108 \\
\hline 220 & 44.40 & 44.18 & 0.130 & 0.079 & 0.085 & 0.090 & 0.083 & 0.034 & 0.097 & 0.062 & 0.102 & 0.089 \\
\hline 221 & 44.95 & 44.85 & 0.120 & 0.086 & 0.073 & 0.098 & 0.093 & 0.037 & 0.054 & 0.052 & 0.111 & 0.060 \\
\hline 223 & 43.59 & 43.43 & 0.107 & 0.061 & 0.064 & 0.082 & 0.071 & 0.043 & 0.096 & 0.040 & 0.108 & 0.060 \\
\hline 224 & 45.58 & 45.37 & 0.096 & 0.076 & 0.064 & 0.101 & 0.087 & 0.051 & 0.100 & 0.027 & 0.111 & 0.072 \\
\hline
\end{tabular}

Table 8. Crack width results for beam A2M-2 at 0.75 and 0.95 of the actual damage force.

\begin{tabular}{|c|c|c|c|c|c|c|c|c|c|c|c|c|}
\hline \multirow{3}{*}{ Image No. } & \multirow{3}{*}{ Actuator No. $2(\mathrm{kN})$} & \multirow{3}{*}{ Actuator No. $3(\mathrm{kN})$} & \multicolumn{10}{|c|}{ Crack No. } \\
\hline & & & 4 & 5 & 6 & 7 & 8 & 9 & 10 & 11 & 12 & 13 \\
\hline & & & \multicolumn{10}{|c|}{ Crack width (mm) } \\
\hline 270 & 53.39 & 53.31 & 0.124 & 0.102 & 0.087 & 0.111 & 0.107 & 0.058 & 0.091 & 0.049 & 0.115 & 0.110 \\
\hline 345 & 68.44 & 68.26 & 0.230 & 0.100 & 0.109 & 0.134 & 0.150 & 0.184 & 0.135 & 0.086 & 0.154 & 0.120 \\
\hline
\end{tabular}


The history of crack formation versus the bending moment in the middle segment $X=1000 \mathrm{~mm}$ in length on the A2M-2 beam side surface is shown in Figures 23 and 24. The vertical lines in Figure 23 illustrate the cracks formed at various loading levels (bending moments). The distances between the vertical lines correspond to those between the cracks at a given load. The number of cracks equals the number of vertical lines. Crack density refers to the number of cracks per $1 \mathrm{~m}$.

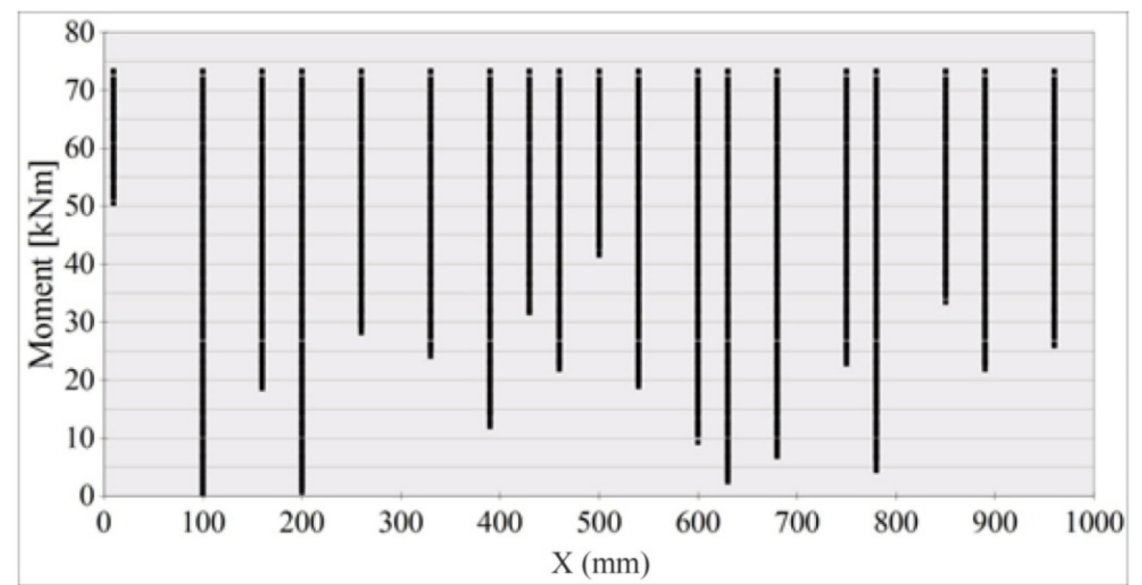

Figure 23. Crack formation and density under loading-beam A2M-2.

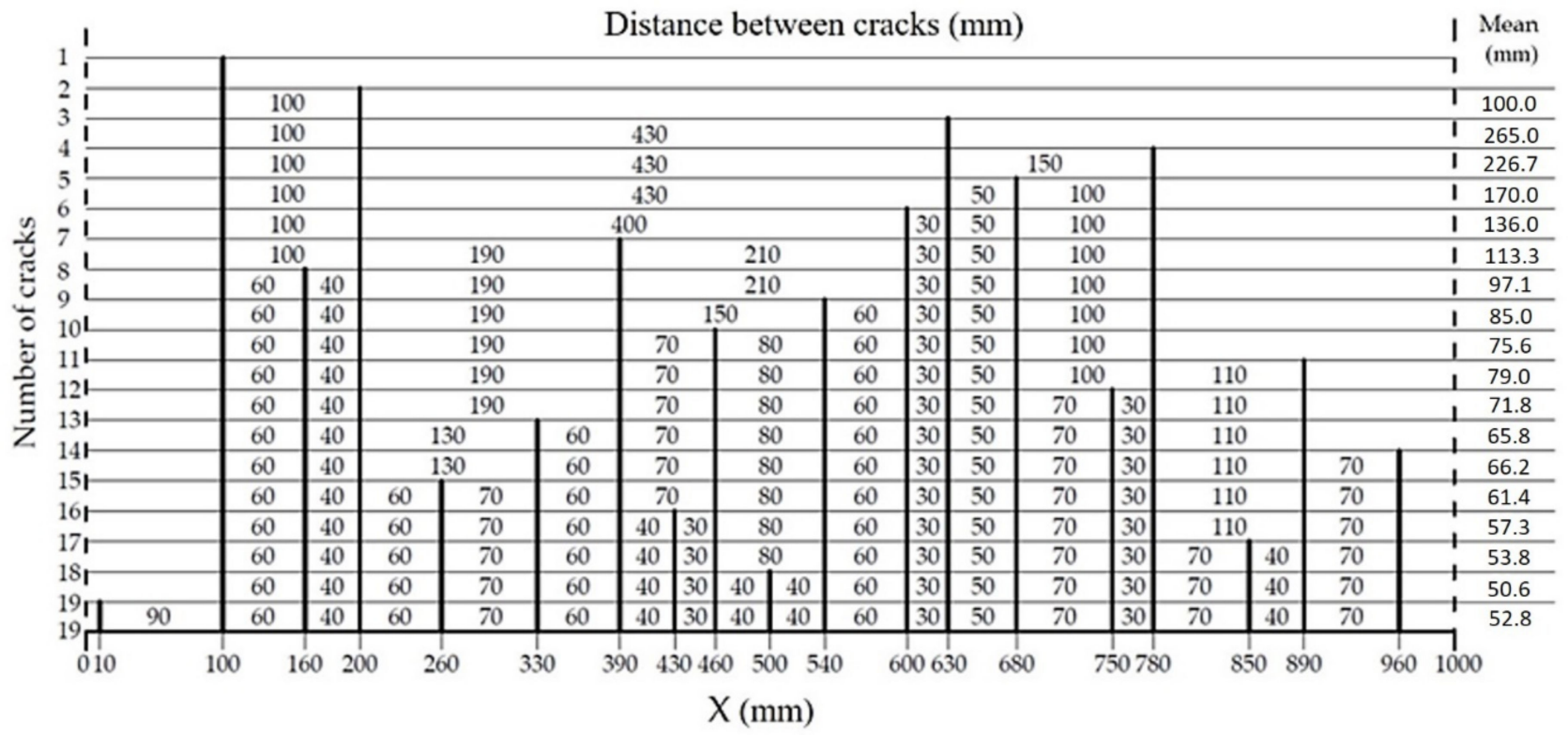

Figure 24. Summary of distances between cracks while loading beam A2M-2.

Deterministic crack formation criteria lead to a description in which all cracks are formed simultaneously over the entire section of the beam, where the moment reaches the critical value for cracking. The cracking on the middle section of the beam, between the forces, proceeds gradually, despite the constant value of the bending moment in this section, and new cracks appear even at the load that significantly exceeds the cracking load. Therefore, it can be concluded that cracks in the beam subjected to pure bending action under increasing load initiate successively as a result of a random spread of strength and forming limit in tension, which proves that both the distance between cracks and crack width are, in fact, stochastic processes. The deterministic description of the distance between the cracks can only refer to the final state of the cracking process. 
The relationship in Figure 23 was used to calculate the distances between consecutive cracks, listed (for the A2M-2 beam) in Figure 24. The calculated mean inter-crack distance was taken.

A crack formation diagram similar to that in Figure 23 is shown in Figure 25 for the A2M- 1 beam, and in Figures 26 and 27 for cyclically loaded A2C-1 and A2C-2 beams, respectively.

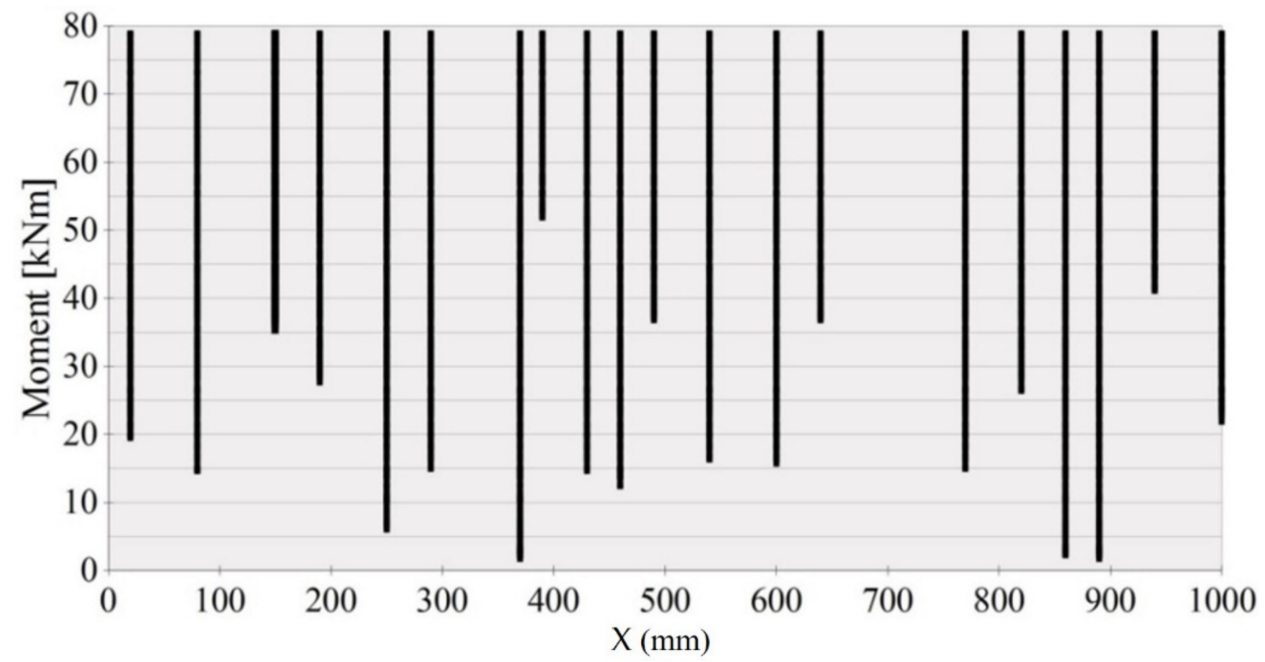

Figure 25. Crack formation and density under loading-beam A2M-1.

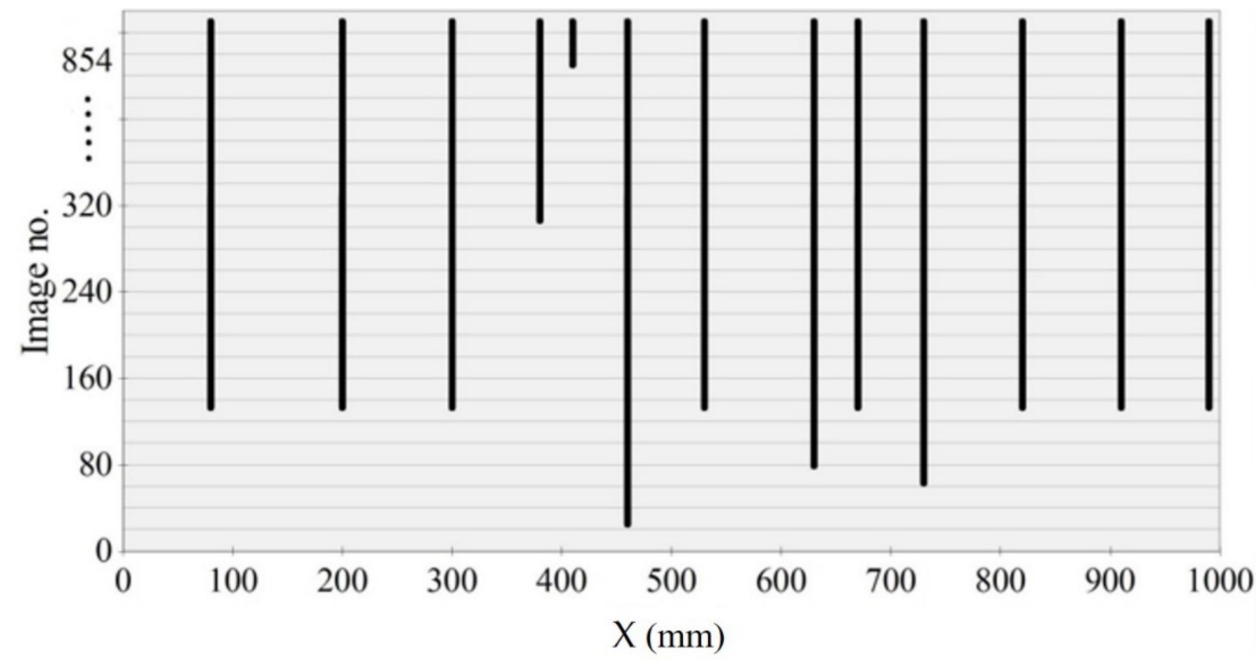

Figure 26. Crack formation and density under loading-beam A2C-1.

The results confirm that the crack formation and development are stochastic, regardless of the loading program. The non-parametric tests (U Mann-Whitney or Kruskal-Wallis) used to analyze the results obtained, lead to the conclusion that there is no correlation between crack distances and loading method.

The crack formation graphs were used to determine the third quantity describing the cracking state, i.e., the cracking moment. Table 9 compiles the values and location of the first crack in eight beams tested, and the calculated relative cracking moment value against the breaking/failure moment. The scatter of the results is relatively high. 


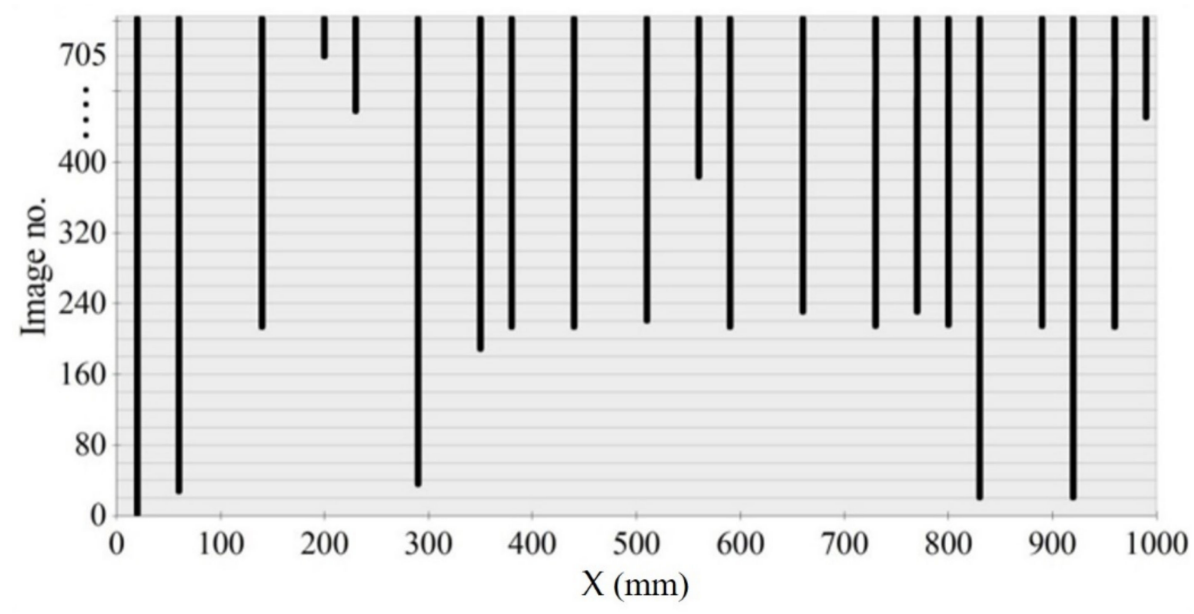

Figure 27. Crack formation and density under loading-beam A2C-2.

Table 9. Location of the first crack and the value of the cracking moment for beams in bending.

\begin{tabular}{cccccccccc}
\hline Beam & A2M-1 & A2M-2 & D2M-1 & D2M-2 & C2M-1 & C2M-2 & A2O-1 & A2O-2 \\
\hline$X(\mathrm{~mm})$ & 370 and 890 & 100 & 680 & 890 & 870 & 960 & 20 & 710 \\
\hline Cracking moment $(\mathrm{kNm})$ & 1.87 & 0.67 & 8.62 & 14.49 & 11.87 & 4.16 & 3.23 & 9.66 \\
\hline Relative cracking moment & 0.024 & 0.009 & 0.102 & 0.183 & 0.138 & 0.051 & 0.04 & 0.13 \\
\hline
\end{tabular}

Analysis of the results confirms that the crack width and the distance between the cracks depend on the moment value, while the cracking moment is not moment-dependent. A small cracking moment in beams A2M-1, A2M-2 and A2O-1 proves that during concrete hardening, some action (e.g., concrete demoulded too early) resulted in the formation of an internal network of micro-cracks in its structure. Therefore, immediately after the load was applied, the internal microcracks developed into cracks visible on the side surface of the beams. This shows that many factors, some difficult to establish, affect the formation of cracks in concrete elements and that it is essential to test early age concrete.

\section{Crack Width Calculation}

Crack width is a crucial characteristic for the cracking limit state because it is the crack width, or rather its maximum value that decides the durability of concrete structures. Checking the cracking limit state of a structure consists of calculating whether cracks will appear in the structure under the influence of loads or, more generally, actions on the structure, or whether the crack width exceeds the permissible size. Thereby the calculations involve the estimation of the maximum value, which, as it depends on many factors, is characterized by a substantial random scatter and thus, the estimate will be more or less accurate. From a practical point of view, it is therefore important to estimate the maximum crack width in a safe and relatively simple manner.

As proposed in [27], the probabilistic under-load behavior model for the area between the cracks, shown in Figure 28, enables the formulation of a simplified formula for calculating the crack widths due to bending perpendicular to the axis of the element. In this model [27], in order to take into account the influence of existing cracks on the formation of new ones, it was assumed that in parts left and right of the crack ( $\mathrm{a}^{\prime}$ and $\mathrm{a}^{\prime \prime}{ }^{\prime}$, Figure 28), the decrease in concrete stress excludes the formation of a new crack. It follows that the strain difference between steel and concrete can only occur in this section. It is called the passive section of length 2aw. Thus, the crack width can be calculated from Formula (6).

$$
\mathrm{w}=2 \mathrm{a} \omega \varepsilon_{\mathrm{s}}
$$

where: 
$\mathrm{w}$-crack width,

$a^{\prime}, a^{\prime \prime}$-passive section measured from the cross-section with the crack,

$2 \mathrm{a}=\mathrm{a}^{\prime}+\mathrm{a}^{\prime \prime}$

$\varepsilon_{s}$-steel strain in the section with the crack,

$\omega \leq 1$-geometric factor for steel and concrete strain differences in section a.

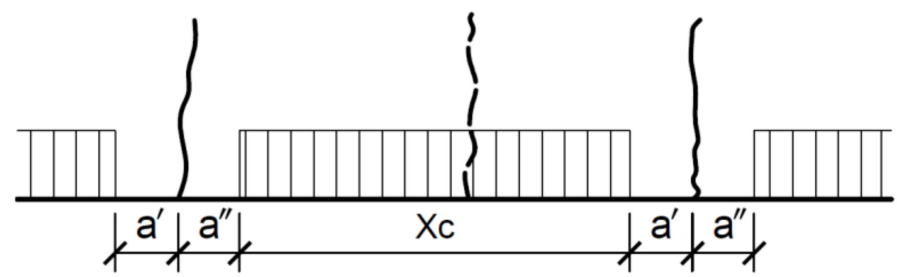

Figure 28. Model of crack formation-passive section a and active section $\mathbf{x}_{\mathbf{c}}$.

The size of the area surrounding the crack, where stress decreases, is generally a random function. However, in search of a simplified formula, the continuous changes of the crack width were measured using the DIC system. The measurement of the crack width development under loading indicates the linear increase of up to 0.9 of the failure force [42], as shown by examples of cracks no. 2 and 14 (Figure 29) on beam D2M-2 and crack no. 11 on beam C2M-2 (Figure 30). This was confirmed by analyzing the average crack width increase for individual beams, as shown in Figure 31. It can thus be concluded that the course of changes in the section 2aw length can be assumed as linear.

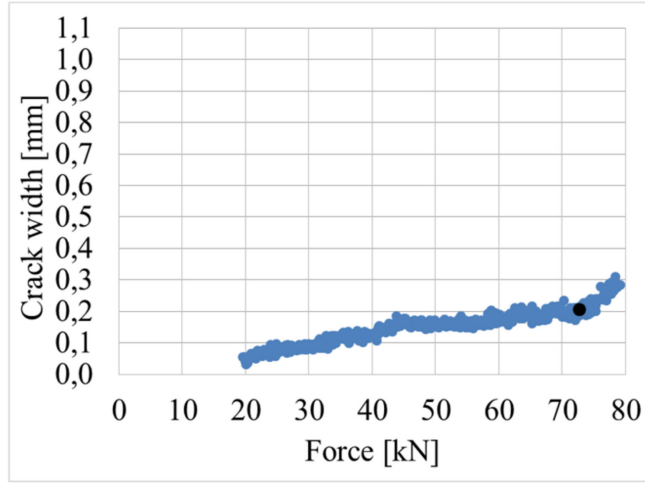

(a)

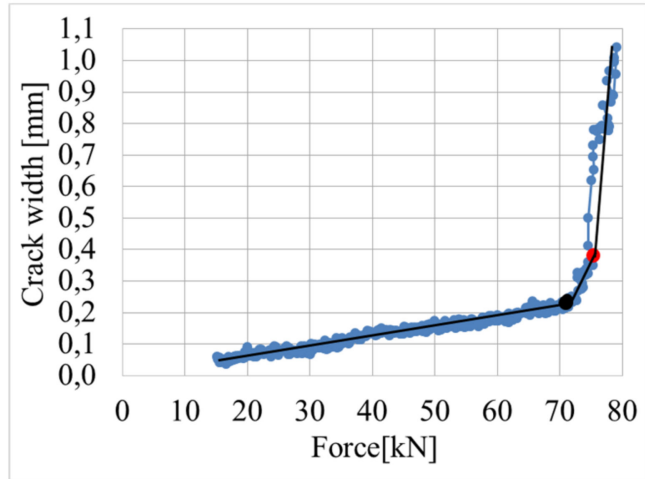

(b)

Figure 29. Increase in the width of cracks on beam D2M-2 during loading (a) crack no. 2; (b) crack no. 14.

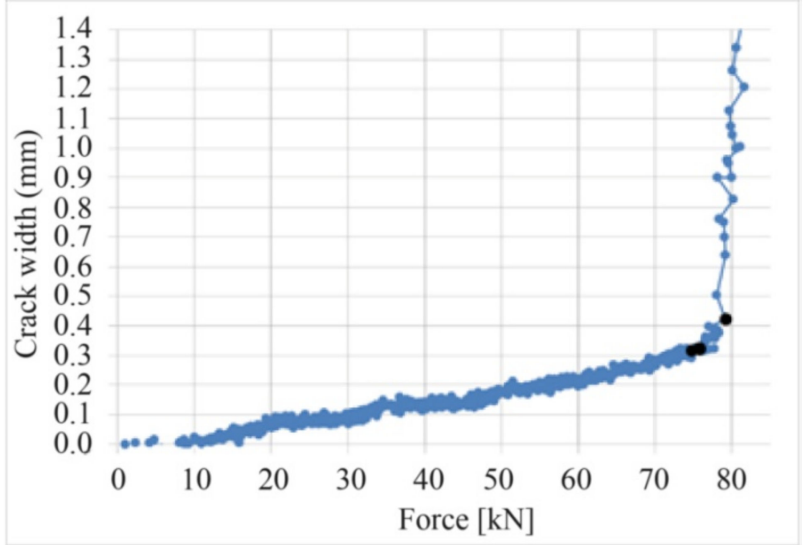

Figure 30. Increase in the width of crack no. 11 on beam C2M-2 during loading. 


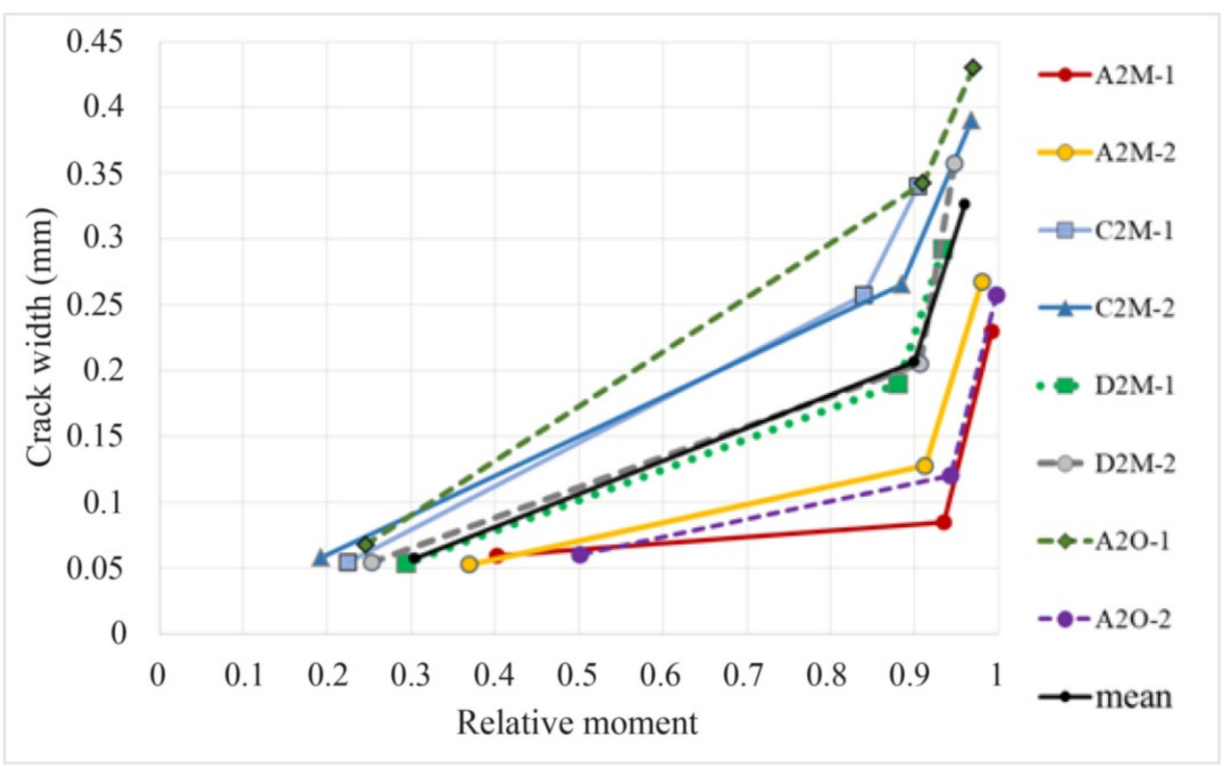

Figure 31. Increase in the mean crack width on individual beams under loading.

Known crack width enables the estimation of the 2aw value which is the product of the length of the bond loss section $2 a=a^{\prime}+a^{\prime \prime}$ and the geometric factor for strain differences between steel and concrete $\omega \leq 1$.

$$
2 \mathrm{aw}=\frac{\mathrm{w}}{\varepsilon_{\mathrm{s}}}
$$

where:

$$
\varepsilon_{\mathrm{s}}=\frac{\mathrm{M}}{\mathrm{zA}_{\mathrm{s} 1} \mathrm{E}_{\mathrm{s}}}
$$

in which:

$\mathrm{M}$-bending moment value

$\mathrm{A}_{\mathrm{s} 1}$ - cross sectional area of tension reinforcement

$\mathrm{E}_{\mathrm{s}}$-steel modulus of elasticity

$\mathrm{z}$-lever arm of internal forces of the flexure section.

The lever arm of internal forces in cracked flexure sections does not change significantly in the loading process, so, without much error, it is possible to take this value as a constant and calculate it based on the work of the section in bending in phase IIa (cracked cross section, linear plot of stresses in compressed concrete). Since BS500 steel reinforcement was used in the compression zone of the tested RC beams, the maximum internal force arm was assumed to be:

$$
\mathrm{z}=\mathrm{d}-\mathrm{d}_{2}
$$

where:

d-effective depth of a cross-section

$\mathrm{d}_{2}$-distance of compression edge of the beam section to the centroid of the compression reinforcement.

The maximum crack width was obtained from the DIC system at selected load levels for the tested five beams with a constant moment in the central segment, and the value of 2aw was calculated from Formula (7). The results of the calculations are given in Table 10 together with the fixed maximum, minimum and mean values. 
Table 10. Maximum, minimum and mean value of 2aw for maximum crack width.

\begin{tabular}{ccccccccc}
\hline \multirow{2}{*}{ Relative Moment } & \multicolumn{9}{c}{ 2aw (mm) } & \multicolumn{1}{c}{} \\
\cline { 2 - 10 } & A2M-1 & A2M-2 & D2M-1 & D2M-2 & A2O-1 & Maximum & Minimum & Mean \\
\hline 0.25 & 132.77 & 139.38 & 87.40 & 85.67 & & 139.38 & 85.67 & 111.30 \\
\hline 0.32 & 70.17 & 74.76 & 96.34 & 106.59 & 113.07 & 113.07 & 70.17 & 92.19 \\
\hline 0.5 & 83.42 & 79.41 & 100.40 & 91.60 & & 100.40 & 79.41 & 88.71 \\
\hline 0.58 & 96.47 & 88.45 & 102.28 & 98.57 & 118.26 & 118.26 & 88.45 & 100.80 \\
\hline 0.75 & 62.51 & 71.75 & 91.72 & 101.68 & & 101.68 & 62.51 & 81.91 \\
\hline 0.83 & 59.93 & 63.65 & 97.81 & 99.08 & 127.04 & 127.04 & 59.93 & 89.50 \\
\hline
\end{tabular}

The obtained results are presented graphically in Figure 32. The points in the figure correspond to the calculated mean, maximum and minimum value of $2 \mathrm{a} \omega$, and the solid line is described by Relationship (8) obtained using the least squares method (LSM).

$$
2 \mathrm{a} \omega=-30.53 \frac{\mathrm{M}}{\mathrm{M}_{\max }}+110.50
$$

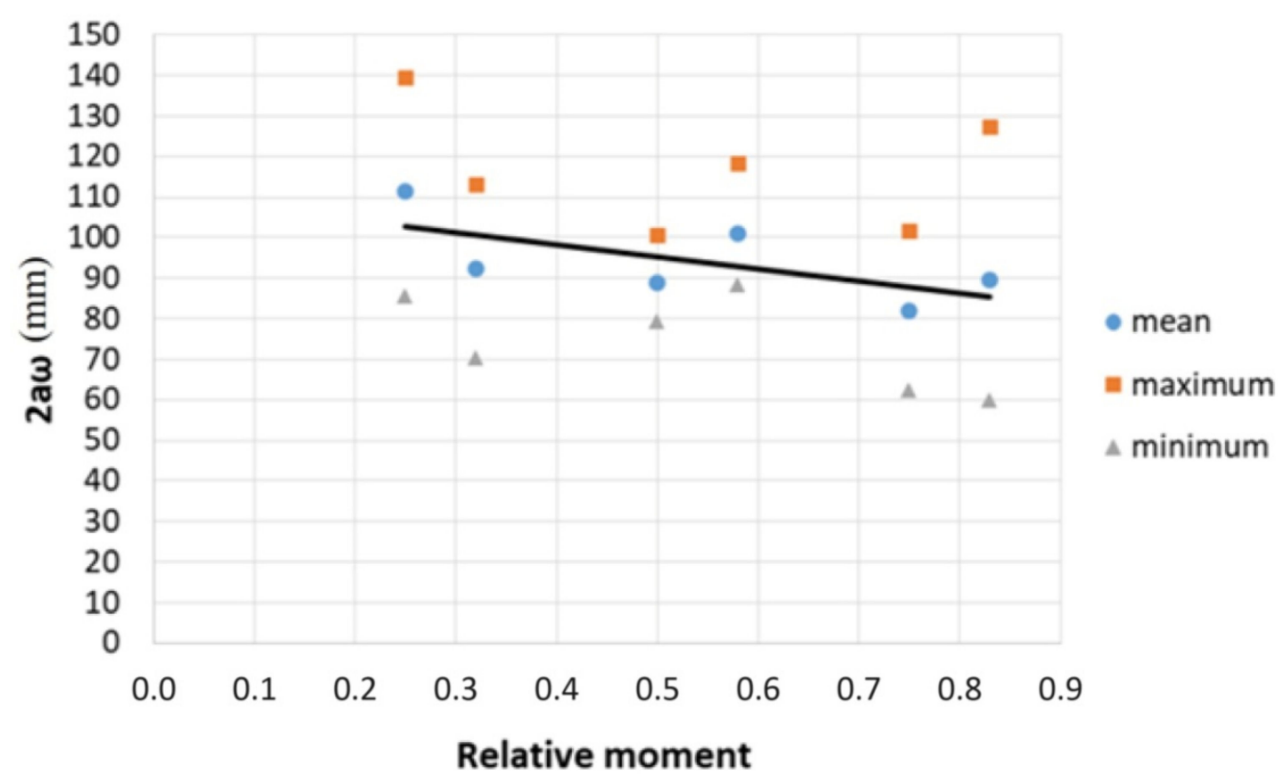

Figure 32. Section 2aw by relative moment.

When analyzing the Figure 32, it can be noticed that the point with the coordinates $[0.83 ; 127.04]$ is the farthest from the solid line obtained by LSM. Considering that the durability of the concrete structure is decided by the cracks with the maximum width, crack width estimations must give safe results. Hence, the solid line obtained by LSM was shifted by the vector $v[0 ; 41.88]$ and intersects point with coordinates [0.83; 127.04], as shown in Figure 33. To stay on the safe side, to determine the bond loss segment section, relationship (9) was adopted.

$$
2 \mathrm{a} \omega=-30.53 \frac{\mathrm{M}}{\mathrm{M}_{\max }}+152.38
$$




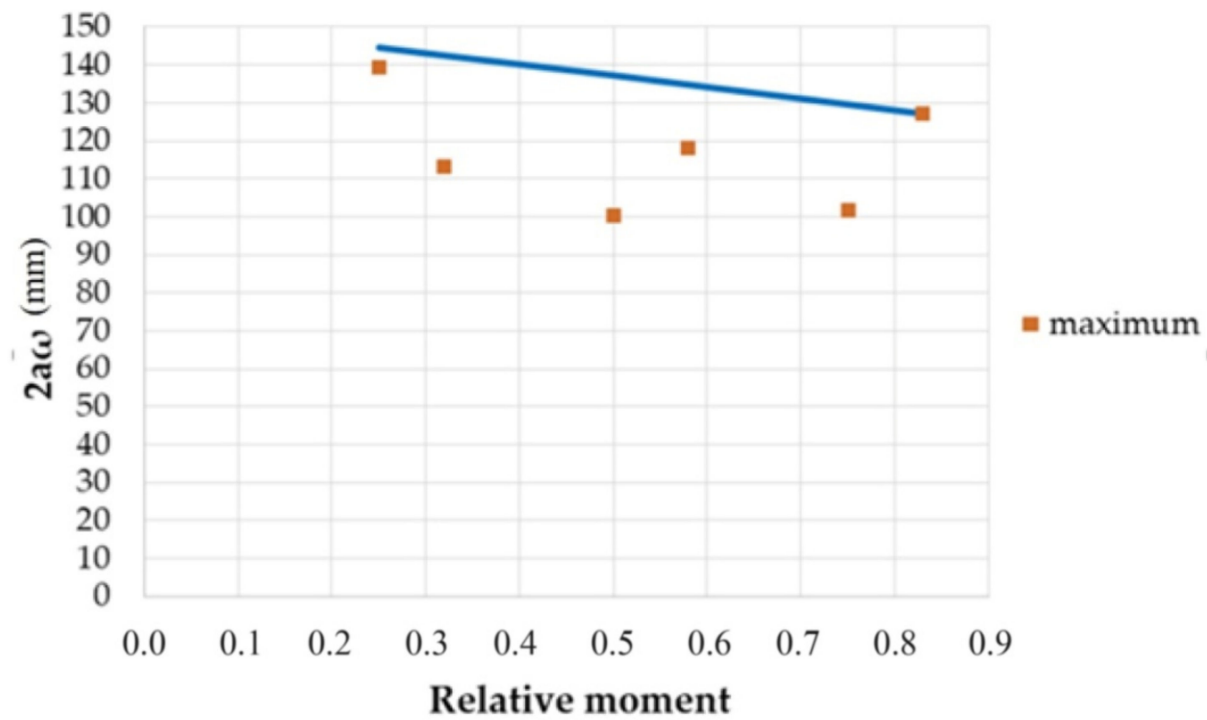

Figure 33. Maximal section 2aw by relative moment.

Table 11 compiles the results of crack width calculations from Formula (6) at selected load levels with the use of Relationship (9).

Table 11. Summary of the crack width calculations at selected load levels.

\begin{tabular}{ccccccccc}
\hline \multicolumn{1}{c}{ Beam } & \multicolumn{7}{c}{ Crack Width (mm) } \\
\cline { 2 - 10 } & $\mathbf{0 . 4}$ & $\mathbf{0 . 4 5}$ & $\mathbf{0 . 5}$ & $\mathbf{0 . 5 5}$ & $\mathbf{0 . 6}$ & $\mathbf{0 . 6 5}$ & $\mathbf{0 . 7}$ & $\mathbf{0 . 7 5}$ \\
\hline A2M-1 & 0.17 & 0.189 & 0.208 & 0.226 & 0.244 & 0.261 & 0.278 & 0.294 \\
\hline A2M-2 & 0.164 & 0.182 & 0.2 & 0.218 & 0.235 & 0.252 & 0.268 & 0.284 \\
\hline D2M-1 & 0.182 & 0.203 & 0.223 & 0.242 & 0.261 & 0.28 & 0.298 & 0.315 \\
\hline D2M-2 & 0.175 & 0.195 & 0.214 & 0.233 & 0.251 & 0.27 & 0.287 & 0.303 \\
\hline C2M-1 & 0.183 & 0.203 & 0.224 & 0.243 & 0.262 & 0.281 & 0.299 & 0.317 \\
\hline C2M-2 & 0.175 & 0.194 & 0.214 & 0.232 & 0.251 & 0.268 & 0.286 & 0.303 \\
\hline Mean & 0.175 & 0.194 & 0.214 & 0.232 & 0.251 & 0.269 & 0.286 & 0.303 \\
\hline
\end{tabular}

Figure 34 compares the experimental results, the results calculated according to the simplified Formula (6), assuming Relationship (9), and the results of the maximum crack width calculations to EC2. The horizontal line in the drawing corresponds to the permissible crack width of $0.3 \mathrm{~mm}$.

Analysis shows that estimating the crack width from the simplified Formula (6), assuming the value of 2aw from Dependence (9) based on the concept of the probabilistic model of crack formation presented in Figure 28, allows a safe-sided estimation of the maximum crack width. This estimation method is more consistent with the experimental results and is on the safe side compared to the estimation based on the formulas given in EC2. 


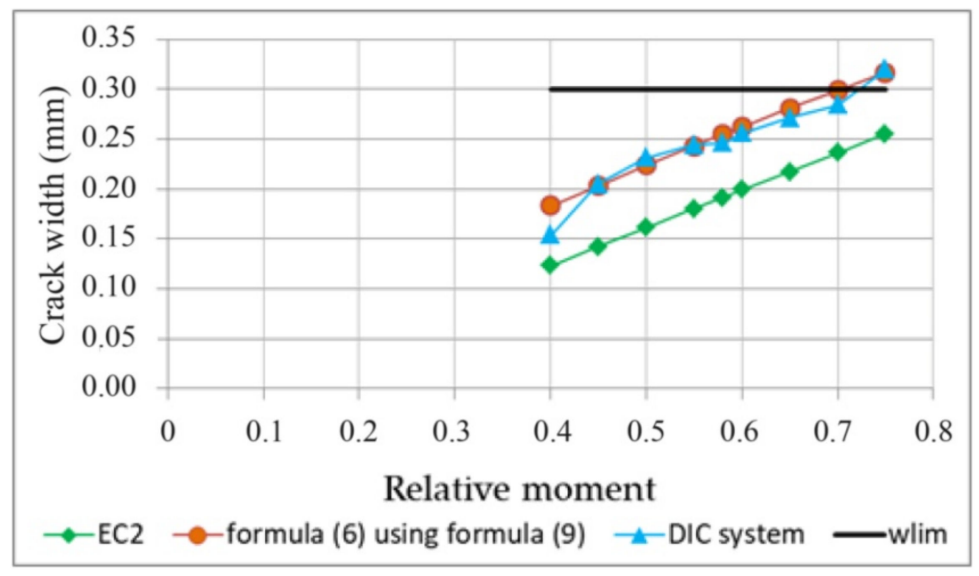

Figure 34. Crack widths at selected levels of critical stress-strain state.

\section{Discussion}

The reliability and durability of a reinforced concrete element is closely related to the extent and severity of concrete cracking, which has a profound effect on reinforcement protection against corrosion. Concrete cracking research follows two approaches.

One approach is based on the fracture mechanics and modeling of concrete resistance including cracking. This approach looks at the influence of concrete mix components, aggregate size, internal mage, additives used and stress. Fracture mechanics and fracture toughness modeling have been covered in many papers [10-17]. Development of these issues is very important for numerical modeling of the performance of concrete elements. Their practical application is in design, including proper design of reinforcement.

The second approach, which is presented in this paper, is the tracking of crack pattern and crack width changes, utilized toward the development of methods for the assessment of reinforced concrete structures. The process of the loading of reinforced concrete beams is accompanied by the process of crack formation. As the load increases, the initially rapid changes in the crack pattern decrease and the pattern gradually stabilizes. The crack formation process depends on many factors, but for a given element it is a function of the load. It is thus a function of one variable, and the quantities such as shape, section dimensions, type of reinforcing steel, concrete mix composition, etc., act as parameters. The combined effect of these factors determines the intensity of the process which is a function of load. The crack intensity is the number of cracks per unit length of the element and the crack width, which determines the corrosion protection of the reinforcing bars. The paper presents the results of an extensive research program on reinforced concrete beams subjected to monotonic loads, and cyclic loads. The research presented in this paper was carried out with a view to developing a method for diagnosing reinforced concrete bridges; in particular, using the acoustic emission method [24,25]. Since the durability of reinforced concrete structures depends on the intensity of cracking and crack width, a parallel study was undertaken concerning the tracing of the crack formation process and development. Knowledge of the density function describing the distribution of distances between cracks in the process of loading and changes in the crack width would provide a reliable method of assessing the $\mathrm{RC}$ structure condition based on artificial intelligence. Topics related to the determination of the density function describing the distribution of distances between cracks have been addressed previously [2]. However, hardware possibilities in the field of computer capacity as well as testing equipment in the field of alternating loads and continuous crack width observation available in those time have stopped further development. The use of a program able element loading controller and an ARAMIS optical system for examining the lateral surface $(1.2 \mathrm{~m} \times 0.30 \mathrm{~m})$ of the beam between the forces, enabled the continuation of the earlier subject matter. The results of the study of 10 reinforced concrete beams loaded according to 3 programs of monotonic 
loading to failure, with unloads loads, and cyclic loading gave a quantitative sufficient set of data to draw conclusions from the analyses. It was found that:

- The obtained results of continuous measurement of crack width changes during the loading process allowed the formulation of a simplified formula for estimating the maximum crack width;

- The maximum crack widths estimated on the basis of the proposed simple relation were on the safe side in relation to those calculated according to the Eurocode 2;

- The results of the analysis of the distances between cracks developed in the form of drawings and tables illustrate that the formation and development of cracks is a stochastic process, and also allows the conclusion that there is no relationship between the distances between the cracks and the method of loading;

- The optical system consisted of a tripod with an arm (distance between cameras) that ensured the observation of surfaces of dimensions $1.5 \mathrm{~m} \times 1.0 \mathrm{~m}$ for use in the study of the process of crack formation and development in reinforced concrete beams.

The obtained results are the basis for further work, that will include consideration of diagonal cracks that arise at the section of the combined action of the bending moment and transverse forces, and the preparation of the experimental function of crack density and its verification.

Author Contributions: Conceptualization, B.G.; Methodology, B.G., W.T. and J.T.; Software, J.T.; Validation, B.G. and W.T.; Formal Analysis, W.T.; Investigation, J.T.; Resources, B.G. and J.T.; Data Curation, J.T.; Writing-Original Draft Preparation, J.T.; Writing-Review and Editing, W.T.; Visualization, J.T.; Supervision, B.G.; Project Administration, B.G.; Funding Acquisition, B.G. All authors have read and agreed to the published version of the manuscript.

Funding: This research was founded by The National Centre for Research and Development grant number [N R04 000 710].

Institutional Review Board Statement: Not applicable.

Informed Consent Statement: Not applicable.

Data Availability Statement: Data available in a publicly accessible repository.

Conflicts of Interest: The authors declare no conflict of interest.

\section{References}

1. Arel, H. Şahan Recyclability of waste marble in concrete production. J. Clean. Prod. 2016, 131, 179-188. [CrossRef]

2. Goszczyńska, B. Description of Empirical Process of Crack Formation in Framework of Probabilistic Theory. Arch. Civ. Eng. 2002, 48, 405-423.

3. Alam, S.Y.; Lenormand, T.; Loukili, A.; Regoin, J.P. Measuring Crack Width and Spacingin Rein-forced Concrete Members. In Proceedings of the 7th International Conference on Fracture Mechanics of Concrete and Concrete Structures (FraMCoS-7), Seogwipo, Korea, 23-28 May 2010; pp. 377-382.

4. Hamrat, M.; Boulekbache, B.; Chemrouk, M.; Amziane, S. Flexural cracking behavior of normal strength, high strength and high strength fiber concrete beams, using Digital Image Correlation technique. Constr. Build. Mater. 2016, 106, 678-692. [CrossRef]

5. Oh, B.H.; Kim, S.H. Advanced Crack Width Analysis of Reinforced Concrete Beams under Repeated Loads. J. Struct. Eng. 2007, 133, 411-420. [CrossRef]

6. Li, C.-Q.; Yang, S. Prediction of Concrete Crack Width under Combined Reinforcement Corrosion and Applied Load. J. Eng. Mech. 2011, 137, 722-731. [CrossRef]

7. Elgohary, H.A.; Assas, M.M. New Design Approach for Crack Width Calculation in Reinforced Concrete Structures. In Research and Applications in Structural Engineering, Mechanics and Computation; Zingoni, A., Ed.; Taylor \& Francis Group: London, UK, 2013; pp. 1555-1558. ISBN 978-1-138-00061-2.

8. Subramanian, N. Controlling the Crack Width of Flexural RC Members. Indian Concr. J. 2005, 79, 31-36.

9. Kelpša, Š.; Augonis, M.; Daukšys, M.; Augonis, A. Analysis of Crack Width Calculation of Steel Fibre and Ordinary Reinforced Concrete Flexural Members. J. Sustain. Arch. Civ. Eng. 2014, 6, 50-57. [CrossRef]

10. Golewski, G.; Sadowski, T. Fracture Toughness at Shear (Mode II) of Concretes Nade of Natural and Broken Aggregates. In Brittle Matrix Composites 8; Elsevier: Amsterdam, The Netherlands, 2006; pp. 532-546.

11. Sadowski, T.; Golewski, G. Effect of Aggregate Kind and Graining on Modeling of Plain Concrete under Compression. Comput. Mater. Sci. 2008, 43, 119-126. [CrossRef] 
12. Golewski, G.L. Wykorzystanie systemu Aramis do analizy propagacji rys pierwotnych w betonach z dodatkiem popiołów lotnych. Przegląd Bud. 2010, 81, 30-35. (In Polish)

13. Zhang, C.; Han, S.; Hua, Y. Flexural performance of reinforced self-consolidating concrete beams containing hybrid fibers. Constr. Build. Mater. 2018, 174, 11-23. [CrossRef]

14. Li, L.; Li, Z.; Cao, M.; Tang, Y.; Zhang, Z. Nanoindentation and porosity fractal dimension of calcium carbonate whisker reinforced cement paste after elevated temperatures (UP TO $900{ }^{\circ} \mathrm{C}$ ). Fractals 2021, 29, 2140001. [CrossRef]

15. Sucharda, O.; Mateckova, P.; Bilek, V. Non-Linear Analysis of an RC Beam Without Shear Reinforcement with a Sensitivity Study of the Material Properties of Concrete. Slovak J. Civ. Eng. 2020, 28, 33-43. [CrossRef]

16. Li, L.; Cao, M.; Xie, C.; Yin, H. Effects of $\mathrm{CaCO} 3$ whisker, hybrid fiber content and size on uniaxial compressive behavior of cementitious composites. Struct. Concr. 2019, 20, 506-518. [CrossRef]

17. Valikhani, A.; Jahromi, A.J.; Mantawy, I.M.; Azizinamini, A. Numerical Modelling of Concrete-to-UHPC Bond Strength. Materials 2020, 13, 1379. [CrossRef] [PubMed]

18. Abou-Zeid, M.; Fowler, D.W.; Nawy, E.G.; Allen, J.H.; Halvorsen, G.T.; Poston, R.W.; Barlow, J.P.; Hansen, W.; Rhoads, R.J.; Brander, M.E.; et al. Control of Cracking in Concrete Structures; Reported by ACI Committee 224; American Concrete Institute: Farmington Hills, MI, USA, 2001; Volume 224, pp. 12-16.

19. Goszczyńska, B.; Tworzewska, J. Określenie rysy na potrzeby analizy wyników badania procesu powstawania i rozwoju rys w belkach żelbetowych z zastosowaniem systemu ARAMIS. Przegląd Bud. 2014, 12, 44-49. (In Polish)

20. Lai, J.; Cai, J.; Chen, Q.-J.; He, A.; Wei, M.-Y. Influence of Crack Width on Chloride Penetration in Concrete Subjected to Alternating Wetting-Drying Cycles. Materials 2020, 13, 3801. [CrossRef]

21. Basteskår, M.; Engen, M.; Kanstad, T.; Fosså, K.T. A review of literature and code requirements for the crack width limitations for design of concrete structures in serviceability limit states. Struct. Concr. 2019, 20, 678-688. [CrossRef]

22. Piyathilaka, L.; Preethichandra, P.; Izar, U.; Kahandawa, G. Real-Time Concrete Crack Detection and Instance Segmentation using Deep Transfer Learning. Eng. Proc. 2020, 2, 91. [CrossRef]

23. Liebold, F.; Heravi, A.A.; Mosig, O.; Curbach, M.; Mechtcherine, V.; Maas, H.-G. Crack Propagation Velocity Determination by High-speed Camera Image Sequence Processing. Materials 2020, 13, 4415. [CrossRef]

24. Goszczyńska, B. Analysis of the process of crack initiation and evolution in concrete with acoustic emission testing. Arch. Civ. Mech. Eng. 2014, 14, 134-143. [CrossRef]

25. Goszczyńska, B.; Świt, G.; Trampczyński, W. Analysis of the microcracking process with the Acoustic Emission method with respect to the service life of reinforced concrete structures with the example of the RC beams. Bull. Pol. Acad. Sci. Tech. Sci. 2015, 63, 55-63. [CrossRef]

26. Eurocode 2: Design of Concrete Structures_Part 1-1: General Rules and Rules for Buildings; EN 1992-1-1; CEN (European Committee for Standardization): Brussels, Belgium, 2008.

27. Goszczyńska, B. Losowy Proces Powstawania rys w Strefie Czystego Zginania Belek Żelbetowych. Ph.D. Thesis, Politechnika Łódzka, Łódź, Poland, 1984. (In Polish).

28. Tyson, J. Optical 3D Deformation and Strain Measurement. In Pumps and Pipes; Springer Science and Business Media LLC: Boston, MA, USA, 2010; pp. 147-164.

29. Domaneschi, M.; Niccolini, G.; Lacidogna, G.; Cimellaro, G.P. Nondestructive Monitoring Techniques for Crack Detection and Localization in RC Elements. Appl. Sci. 2020, 10, 3248. [CrossRef]

30. Krawczyk, Ł.; Gołdyn, M.; Urban, T. Digital Image Correlation Systems in the Experimental Investigations: Capabilities and Limitations. Arch. Civ. Eng. 2019, 65, 171-180. [CrossRef]

31. Ghorbani, R.; Matta, F.; Sutton, M. Full-Field Deformation Measurement and Crack Mapping on Confined Masonry Walls Using Digital Image Correlation. Exp. Mech. 2015, 55, 227-243. [CrossRef]

32. Golewski, G.L.; Sadowski, T. Macroscopic Evaluation of Fracture Processes in Fly Ash Concrete. Solid State Phenom. 2016, 254, 188-193. [CrossRef]

33. Słoński, M.; Tekieli, M. 2D Digital Image Correlation and Region-Based Convolutional Neural Network in Monitoring and Evaluation of Surface Cracks in Concrete Structural Elements. Materials 2020, 13, 3527. [CrossRef] [PubMed]

34. Żaba, K.; Trzepieciński, T.; Puchlerska, S.; Noga, P.; Balcerzak, M. Coupled Thermomechanical Response Measurement of Deformation of Nickel-Based Superalloys Using Full-Field Digital Image Correlation and Infrared Thermography. Materials 2021, 14, 2163. [CrossRef]

35. Paczos, P.; Pawlak, A. Experimental Optical Testing and Numerical Verification by CuFSM of Compression Columns with Modified Channel Sections. Materials 2021, 14, 1271. [CrossRef]

36. Smarzewski, P. Study of Toughness and Macro/Micro-Crack Development of Fibre-Reinforced Ultra-High Performance Concrete after Exposure to Elevated Temperature. Materials 2019, 12, 1210. [CrossRef]

37. Smarzewski, P. Analysis of Failure Mechanics in Hybrid Fibre-Reinforced High-Performance Concrete Deep Beams with and without Openings. Materials 2018, 12, 101. [CrossRef] [PubMed]

38. Ramos, T.; Furtado, A.; Eslami, S.; Alves, S.; Rodrigues, H.; Arêde, A.; Tavares, P.J.; Moreira, P. 2D and 3D Digital Image Correlation in Civil Engineering-Measurements in a Masonry Wall. Procedia Eng. 2015, 114, 215-222. [CrossRef] 
39. Tworzewski, P.; Goszczynska, B. An application of an optical measuring system to reinforced concrete beams analysis. In Proceedings of the 2016 Prognostics and System Health Management Conference (PHM-Chengdu), Chengdu, China, 19-21 October 2016; pp. 1-6.

40. Tworzewski, P. Ocena Stanów Granicznych Zginanych Elementów Żelbetowych za Pomocą Optycznego Systemu Pomiarowego. Ph.D. Thesis, Politechnika Świętokrzyska, Kielce, Poland, 2016. (In Polish).

41. Tworzewski, P.; Tworzewska, J.; Bacharz, M.; Bacharz, K. Application of a 3D Optical Scanner to Reinforced Concrete Elements Analysis. In Proceedings of the Transcom 2013: 10th European Conference of Young Researchers and Scientists, Žilina, Slovakia, 24-26 June 2013; pp. 333-336.

42. Tworzewska, J.; Goszczyńska, B. Badanie przebiegu zmian szerokości rys w procesie obciążania belek żelbetowych. In Konstrukcje Betonowe i Metalowe; Piotrowska, E., Podhorecki, A., Eds.; Uniwersytet Technologiczno Przyrodniczy: Bydgoszcz, Poland, 2015; pp. 121-128. ISBN 9788364235726. (In Polish) 